NBER WORKING PAPER SERIES

\title{
CAPITAL ACCOUNT LIBERALIZATION AND ECONOMIC PERFORMANCE: SURVEY AND SYNTHESIS
}

\author{
Hali J. Edison \\ Michael W. Klein \\ Luca Ricci \\ Torsten Sloek \\ Working Paper 9100 \\ http://www.nber.org/papers/w9100
NATIONAL BUREAU OF ECONOMIC RESEARCH
1050 Massachusetts Avenue
Cambridge, MA 02138
August 2002

A part of this work was used as input for Chapter 4 of the October 2001 World Economic Outlook.The authors thank Tamim Bayoumi, Ross Levine,Dennis Quinn, and Frank Warnock for comments and suggestions and Yutong Li for assistance. The views expressed herein are those of the authors and not necessarily those of the National Bureau of Economic Research.

(C) 2002 by Hali J. Edison, Michael W. Klein, Luca Ricci and Torsten Sloek. All rights reserved. Short sections of text, not to exceed two paragraphs, may be quoted without explicit permission provided that full credit, including (C) notice, is given to the source. 
Capital Account Liberalization and Economic Performance: Survey and Synthesis

Hali J. Edison, Michael W. Klein, Luca Ricci and Torsten Sloek

NBER Working Paper No. 9100

August 2002

JEL No. F32, F33, F36

\begin{abstract}
This paper reviews the literature on the effects of capital account liberalization and stock market liberalization on economic growth. The various empirical measures used to gauge the presence of controls on capital account transactions as well as indicators of stock market liberalization are discussed. We compare detailed measures of capital account controls that attempt to capture the intensity of enforcement with others that simply capture whether or not controls are present. Our review of the literature shows the contrasting results that have been obtained. These differences may reflect differences in country coverage, sample periods and indicators of liberalization. In order to reconcile these differences, we present new estimates of the effects on growth of capital account liberalization and stock market liberalization. We find some support for a positive effect of capital account liberalization on growth, especially for developing countries.
\end{abstract}

Hali J. Edison

International Monetary Fund

Washington, DC 20431

hedison@imf.org

Luca Ricci

International Monetary Fund

Washington, DC 20431

lricci@imf.org
Michael W. Klein

Fletcher School, Tufts University

Medford, MA 02155

and NBER

michael.klein@tufts.edu

Torsten Sloek

International Monetary Fund

Washington, DC 20431

tsloek@imf.org 


\section{INTRODUCTION}

Economic theory suggests that unfettered international capital flows can foster a more efficient allocation of resources, provide opportunities for risk diversification, and help promote financial development. In recognition of these potential benefits, governments of industrial countries have undertaken widespread capital account liberalization over the past quarter-century. Many attribute efficiency gains, increased diversification opportunities, and financial development in these countries to opening up capital markets.

A natural policy prescription, therefore, is to extend this process of international financial integration to other, economically less developed, countries. ${ }^{1}$ But this view has been quite controversial. Some argue that, while capital account liberalization is desirable, it is important to proceed slowly. ${ }^{2}$ Others question the desirability of unfettered capital flows regardless of the liberalization process since, on the grounds that unregulated capital flows could facilitate the occurrence and spreading of currency crises. ${ }^{3}$

\footnotetext{
${ }^{1}$ The benefits of open capital markets were stressed by Lawrence Summers in his 2000 Richard T. Ely Lecture to the American Economic Association when he said "...to the extent that international financial integration represents an improvement in financial intermediation,... [perhaps] because institutions involved in the transfer of capital across jurisdictions improve efficiency with which capital is allocated, it offers a potentially significant increase in economic efficiency." (p. 3)

${ }^{2}$ For example in the Report of the Managing Director to the International Monetary and Financial Committee on Progress in Strengthening the Architecture of the International Financial System and Reform of the IMF it is written "In a number of discussions in recent years on issues related to capital account issues, the Executive Board has emphasized the substantial benefits of capital account liberalization, but stressed the need to carefully manage and sequence liberalization in order to minimize risks."

${ }^{3}$ In an influential article in Foreign Affairs, Bhagwati (1998) argued that "substantial gains [from capital controls] have been asserted, not demonstrated ...” (p. 7).
} 
Given the potential importance of countries' policies on capital account liberalization and the different lessons one might draw based upon which articles one reads in this expanding literature, it seems an opportune time to review the evidence. In this paper we survey the literature on the links between capital account liberalization and economic performance with a focus on the empirical cross-country studies of the effects of capital account liberalization on growth.

One source of the debate on the role of capital account liberalization is the mixed set of empirical results derived in the literature. A possible reason for this ambiguity arises from the difficulty in identifying and quantifying capital account liberalization in a consistent manner across a wide set of countries. Consequently, different studies have applied different empirical measures. Another reason for differences in empirical results is that, while most studies start with essentially the same benchmark cross-country growth model, there is divergence with respect to the set of countries included in the analysis, the sample period that is investigated, the dataset employed, and the estimation technique applied. In order to provide an informative comparison of the various contributions made in the literature, we undertake an empirical analysis to investigate the sensitivity of results to the measure of capital account openness, country coverage, and econometric methods.

The rest of the paper is organized as follows. Section II describes and presents different measures of capital account openness. The presentation of these indicators shows the extent of capital account liberalization across the world over the past quarter century. The description of these indicators is also an important precursor to our summary of the empirical literature on capital account liberalization and economic growth in Section III. Section III compares and contrasts contributions to this literature. We note how these studies 
differ with respect to data, methods and results. These differences hamper comparison across studies. Therefore, in Section IV, we attempt to reconcile some of the differences by presenting results using different indicators of capital account openness in a common data set. In that section, we investigate the sensitivity of the estimated effect of capital account liberalization on economic growth to the use of different indicators of liberalization, to the set of countries used in the analysis, and to the econometric methods employed. The new estimates presented in Section IV provide evidence that capital account liberalization promotes growth, but the significance of this effect varies across regions. Section V offers some concluding remarks.

\section{Measures of Capital Account Restrictions}

A natural starting point for any data-based discussion of the consequences of capital account liberalization is a review of different empirical measures of capital liberalization that have been employed to gauge whether a country allows the free flow of capital across its borders. In practice, there are few indicators of capital account restrictions available across a wide cross-section of countries. Most measures are qualitative and rules-based, though there has been some attempt to go beyond an on/off categorization by reflecting the intensity with which controls are imposed.

Two of the most widely used capital account restriction measures draw on data assembled by the IMF and published annually since 1950 in its Annual Report on Exchange Arrangements and Exchange Restrictions (AREAER). We begin by discussing these rules based indicators. We then present some alternative methods of dating stock market liberalization. Following this, we consider recent quantitative measures. We conclude this 
section with a short discussion of the efficacy of efforts to limit capital flows, a topic that is important when considering the relationship between de jure measures of capital account controls and the de facto effects of these controls.

Table 1 provides a summary of the measures of capital account controls and capital account liberalization. This summary table will facilitate comparing and contrasting the indicators discussed in this section. Each row of this table corresponds to one of the indicators. The first column presents the name of the indicator that we will use in our discussion of the determinants of growth below. The second column provides the source of the indicator, referring either to an article where the indicator is first presented or to a publication whose issues can be used to construct the indicator. Columns 3 through 6 of the table present a brief description of the indicator, the range of values the indicator takes, the years covered and the countries covered by the indicator.

\section{A. Rules-Based Measures}

\section{IMF Measures}

Every issue of the International Monetary Fund's Annual Report on Exchange Arrangements and Exchange Restrictions published between 1967 (which refers to conditions in 1966) and 1996 (which refers to conditions in 1995) includes a summary table in which a single row directly addresses the presence of capital controls; line E.2, labeled "Restrictions on payments for capital transactions." The information in this row has been the

\footnotetext{
${ }^{4}$ The set of categories that reflect the presence of capital controls expanded with the 1997 issue of Annual Report on Exchange Arrangements and Exchange Restrictions with the specification of 13 categories including, for the first time, a distinction between restrictions
} 
basis for generating an indicator of the existence of rules or restrictions that inhibit crossborder capital flows or discriminate on the basis of citizenship or residence of transacting agents. (Table 1, Row 1)

\section{Share Measure}

A standard way to use the information from line E.2 of the International Monetary Fund's Annual Report on Exchange Arrangements and Exchange Restrictions is to construct, for each country, a variable reflecting the proportion of years in which countries had liberalized capital accounts. We call this variable Share (Table 1, Row 2). ${ }^{5}$ For example, if the AREAER judged capital markets open for five years out of a 10 -year period, then the openness measure Share would be 0.5 . A potential problem with this approach is that a value of Share equal to 0.5 is consistent with a situation where a country had open capital markets for the first five years of a decade, for the last five years of a decade, for every other year of a decade, or for many other on-again, off-again patterns. In practice, however, as shown in Panel A of Table 2 (from Klein and Olivei, 2000), there are very few instances of on-again, off-again capital account controls, at least for the 10-year period that ends in 1995, the last

on inflows and restrictions on outflows. Unfortunately, this modification of the classification system introduces a structural break in the measure since the two classification methodologies (one entry versus 13 entries) cannot easily be mapped onto each other. We do not discuss the expanded categorization in the post-1996 AREAER since we know of no research on capital account liberalization that has used data spanning these two classification systems.

${ }^{5}$ The first work to employ such dataset—and generate a publicly available electronic version - was Grilli and Milesi-Ferretti 1995. Other research using such measure includes Rodrik 1998, and Klein and Olivei 2000. 
year in which capital account liberalization reflects the entry in a single line of the AREAER. Thus, over the period 1986 to 1995 , a country with a value of Share equal to 0.1 had an open capital account in 1995 only, a country with a value of Share equal to 0.2 had an open capital account in 1994 and 1995, and so on. This pattern holds for all industrial countries and for 10 of the 12 developing countries that had some experience with open capital accounts during this period. Panel B of this table shows that this correspondence between the value of Share and the number of continuous years of open capital accounts continues to hold for industrial countries as the sample period is extended back to 1976. But, in this longer sample period, there are many more cases of on-again, off-again capital account liberalization among developing countries. In fact, among the developing countries that had any experience with open capital accounts over the period 1976-1995, the only countries where capital accounts were not closed after having been opened were Indonesia and Malaysia, both of which had open capital accounts throughout the entire 1976-1995 period. ${ }^{6}$

\section{An Intensity Measure}

The on/off indicator of capital controls presented in the summary table of the Annual Report on Exchange Arrangements and Exchange Restrictions described above does not distinguish between strongly administered capital controls and those that are somewhat more porous. Quinn (1997) attempts to capture the intensity of enforcement of controls on both the capital account and the current account through a careful reading of the narrative descriptions

\footnotetext{
${ }^{6}$ However, during the 1997/1998 Asian financial crisis Malaysia placed restrictions on its capital account transactions.
} 
in the Annual Report on Exchange Arrangements and Exchange Restrictions (Table 1, Row 3$)^{7}$

We limit our discussion to Quinn's measures of capital account liberalization. ${ }^{8} \mathrm{He}$ scores separately the intensity of controls for capital account receipts and capital account payments. For each of these two categories the scoring method is as follows: a score of 0 indicates payments are forbidden, 0.5 indicates that there are quantitative or other regulatory restrictions, 1 indicates that transactions are subject to heavy taxes, 1.5 indicates that there are less severe taxes, and 2 indicates that transactions are free of restrictions or taxes. The sum of the values for the two categories is an indicator of overall capital account openness that ranges between 0 and 4. These indicators are available annually from 1950-1997 for 21 OECD countries, and for the years 1958, 1973, 1982, and 1988 for 43 non-OECD countries. A glance at Quinn's dataset indicates that the overall trend towards liberalization is mostly driven by the OECD countries. Table 3 presents a tabulation of Quinn's measure of capital account liberalization for 1973, 1982, and 1988, years for which these indicators are available for all countries. The top panel of this table presents the data for the full set of 63 countries while the lower panel presents the data for the 42 non-OECD countries only. The data in the first set of columns of these tables show that, in 1973, 37 of 63 countries, including 26 of the 42 developing countries, had capital account indicators equal to the midrange (2) or lower. The overall trend towards greater capital account liberalization is

\footnotetext{
${ }^{7}$ Two people separately assigned scores based on their readings of the narrative descriptions and then these scores were checked for discrepancies.

${ }^{8}$ Quinn also scores the intensity of controls for four categories related to current account restrictions and a category he calls international legal agreements.
} 
reflected in the fact that, from 1973 to 1988 , the total number of countries with capital account indicators equal to 2 or lower decreased to 33 . But this overall trend hides significant heterogeneity: over the same period the number of developing countries with a score of 2 or lower actually increased to 32 .

As discussed in more detail below, Quinn (1997) uses the change in the value of the indicator of capital account restrictions rather than its level in his growth regressions (Table 1, row 4). The last three columns of each of the two panels in Table 3 uncover interesting patterns in the churning of the capital account liberalization experience. While most OECD countries (18 out of 21) increased their degree of liberalization between 1973 and 1988, the developing countries were almost equally split between those that increased it (15 countries), reduced it (12), or kept it unchanged (15). Note also that by the end of the 1980s, developing countries had converged towards an intermediate level of liberalization; developing countries that had a relatively low level of liberalization in 1973 tended toward an increase in this measure while the opposite held for those developing countries with a relatively high degree of liberalization in 1973.

Quinn's capital account restriction indicators are meant to be used as cardinal numbers and, therefore, there is the implication that a country in category 2 is literally twice as unfettered as one in category 1 , or a change in the value of the indicator of 1 is exactly twice the amount of liberalization as a change in the indicator of 0.5 . A less structured approach for using Quinn's indicators in regressions would involve the creation of dummy variables representing each of the values of the indicators. Alternatively, one might decide to generate fewer dummy variables, say a single dummy variable that takes the value 1 when Quinn's indicator takes the value $0.5,1$, or 1.5 . In the extreme, one may wonder how to 
convert Quinn's measure into a $(0,1)$ dummy, i.e. how to identify which value of Quinn's scale would correspond to a threshold for classifying countries as open or closed.

Table 4 suggests that the correspondence between Quinn's multiple-measures and the 0/1 AREAER measures is approximately achieved if one chooses a threshold of 2 in Quinn's scale. Each of the six panels in this Table offers a tabulation of the number of countries that have capital accounts classified as 0 (closed) or 1 (open) by the AREAER and are given values of capital account restrictions of 0-2 (more closed) or 3-4 (more open) by Quinn. There are three panels for the full sample and three for developing countries, with one pair for each of the more recent years for which Quinn has data for all countries, 1973, 1982, and 1988. A high correspondence between the AREAER and Quinn measures would be reflected in relatively large diagonal elements of the $2 \times 2$ matrix and relatively small off-diagonal elements. In fact, over 80 percent of the countries in the full sample and over 90 percent of the countries for the developing countries sample fall into one of the diagonal cells for each of the three years. For the full sample, there are few cases where the AREAER indicates open capital accounts while Quinn indicates closed capital accounts (that is, it is rare to find a relatively large number in the upper right cell of the $2 \times 2$ matrix). Most of the discrepancies between the two indicators are cases where the AREAER indicates closed capital accounts and Quinn gives a value of $2.5,3,3.5$, or 4 . A more detailed presentation would show that almost all the cases of non-zero entries in the lower-left cell represent a value of 2.5 or 3 assigned by Quinn. Thus, there seems to be quite a high correspondence between Quinn's measures and those of the AREAER, when one chooses a threshold of 2 in Quinn's scale in order to classify a country's capital account as closed or open. The relevant question is 
whether the gradations presented by Quinn offer significant information, a point we return to below.

\section{Other On/Off Measures}

\section{OECD Code of Liberalization of Capital Movements}

An alternative measure of capital account liberalization, albeit one available only for OECD member countries is provided in various issues of the Code of Liberalization of Capital Movements published by the Organization for Economic Cooperation and Development (OECD) about every other year (Table 1, row 5). ${ }^{9}$ Each volume of the Code of Liberalization of Capital Movements offers data on the extent to which restrictions contemporaneously apply on a range of types of international transactions including direct investment, liquidation of direct investment, admission of securities to capital markets, buying and selling of securities, buying and selling of collective investment securities, operations in real estate, financial credits and loans, personal capital movements. The OECD also specifies whether the restrictions apply to commercial banks and other credit institutions, and to institutional investors.

In all, the Code of Liberalization of Capital Movements reports on whether or not there are restrictions on eleven categories of capital account transactions. Klein and Olivei (2001) construct a variable that represents the proportion of these eleven categories that are free of restrictions, averaged over time. Thus, this variable (like the Share variable described

\footnotetext{
${ }^{9}$ Between 1986 and 1985, these volumes were published in March 1986, March 1988, November 1990, June 1993, and 1995.
} 
above) potentially ranges from 0 to 1 over the sample period but (unlike Share) its value for any one country in any year can take a value between 0 and 1 in increments of $1 / 11$. For the period 1986 to 1995, the four largest values for this variable are 0.89 (Germany), 0.92 (United States), 0.921 (Netherlands) and 0.93 (United Kingdom) while two countries have values below one-half, Greece (0.49) and Portugal (0.43). The correlation between this measure and the IMF Share measure using the single annual 0/1 measures drawn from AREAER is 0.86 .

\section{Montiel-Reinhart Intensity Measure}

Montiel and Reinhart in a series of paper develop and use an alternative measure of intensity of controls on international transactions based on annual information for 15 countries (Argentina, Brazil, Chile, Colombia, Costa Rica, Czech Republic, Egypt, Indonesia, Kenya, Malaysia, Mexico, Philippines, Sri Lanka, Thailand, and Uganda) for the period $1990-1996 .^{10}$ This indicator ranges from 0 to 2 and, unlike the measures previously discussed, a higher number represents a stronger capital account restrictions. In particular, a value of 0 for a particular country in a particular year represents a situation where "no restrictions or taxes were imposed on capital inflows and no restrictions on the domestic indebtedness of domestic financial institutions were in place that appeared to be in excess of commonly used prudential measure."11 A value of 1 represents restrictions that take the form

\footnotetext{
${ }^{10}$ See for example, Montiel, 1996; Reinhart and Reinhart 1998; Montiel and Reinhart, 1999.

${ }^{11}$ All the quotes in this paragraph are from Montiel and Reinhart, 1999, notes to Table 3, p. 628.
} 
of "overzealous prudential regulations (such as strict limits on the foreign exchange exposure of banks)" while a value of 2 indicates "the existence of explicit measures, such as prohibitions, deposit requirements, or financial transaction taxes, designed to limit capital flows." (Table 1, row 6 ) The choice of assigning a value of 0,1 , or 2 for a particular country in a particular year is based upon information provided in the annual report of that country's central bank.

Each of the 15 countries in their sample begins with a value of 0 for the capital control proxy in 1990. Ten countries retain a value of 0 throughout the 1990-1996 period and five countries end the period with a value of 2 . More to the point for this discussion, the only instance of an intermediate value of 1 is for Colombia in 1991 and 1992, after which it switches to 2 for 1993-1996. Thus, their effort to distinguish between the intensity of capital controls does not really yield many cases where "mild" capital controls are in place. In particular, were these data used to construct "shares" over the 1990-1996, there would be little difference between using the range of values 0,1 , and 2 or using only 0 and $1 .{ }^{12}$

\section{Stock Market Liberalization Indicators}

Several papers have focused on the liberalization of controls on the international sale or purchase of equities. Research in this area has typically focused on dating the opening of equity markets to foreign investors. Levine and Zervos (1998) and Henry (2000a, 2000b), who extended this work, have compiled dates from a variety of sources including The Wilson

\footnotetext{
${ }^{12}$ Montiel and Reinhart also provide a "sterilization index" which is scored 0,1 , or 2 and which has many more cases of intermediate values than does the capital control proxy.
} 
Directory of Emerging Market Funds, IFC Investable Indexes, various issues of The Economist Intelligence Unit and the IMF's AREAER. For instance, for each of the 11 countries in his sample, Henry uses the dates reflecting official policy decrees as the first date in which a country fund is available, or a 10-percentage point jump in the IFC Investable Index (Table 1, row 7). ${ }^{13}$

Bekaert (1995) and Bekaert and Harvey (1995) also determine dates when equity markets in emerging economies opened to foreign investors based upon a variety of indicators including Official Liberalization Dates, the date of introduction of American Depository Receipts (ADR), the date of the introduction of country funds, and a date estimated through a regime-switching model based on the time series of net U.S. capital flows (see Table 1 in Bekaert and Harvey, 2000). The number of countries covered is extended in a paper by these two authors and Lundblad (2001) to 95 countries, 16 of which had liberalized stock markets over the full period 1980 to 1997 and 27 of which had some experience with stock market liberalizations over this period. (See their Appendix Table A1; these dates are referred to in our Table 1, row 8).

Table 5 presents the dates of "Official International Financial Liberalization" for the 30 countries classified as either emerging markets or frontier markets by the International Finance Corporation, as reported by Bekaert, Harvey, and Lundblad (2001). Note that, in

\footnotetext{
${ }^{13}$ For a description of his method, see the discussion on p. 533 of Henry, 2000a. Table 1 in this paper (p. 534) lists the dates and Table II compares these dates with those used by other authors. This paper is available on his web page. Henry also makes available on his web page a document that lists major policy events, drawn from various issues of the Economist Intelligence Unit's Quarterly Economic Report, "Appendix 1: Chronological Listing of Major Policy Events in Developing Countries." This includes the 11 countries included in his Table 1 as well as Taiwan. See
} 
comparing the entries in this table with the entries in Table 2, only Indonesia and Malaysia had both equity market liberalization and capital account liberalization (as reported by the IMF in the $A R E A E R$ ) and, equity market liberalization followed capital account liberalization for both of these countries.

A recent study by Edison and Warnock (2001) provides a new measure of restrictions on foreign ownership of domestic equities, which shows the intensity of controls at a point in time as well as their evolution over time. The measure, discussed in full details in their article and used in cross-sectional work of Ahearne, Griever, and Warnock (2000), builds on the work of the International Finance Corporation. In particular, for emerging market countries, the IFC publishes two indexes of equity prices, the Global (IFCG) and Investable (IFCI) indexes. Since the IFCI index is comprised of IFCG stocks minus the portion not available to foreigners, the ratio of the market capitalizations of the IFCI to IFCG indexes is a measure of the availability of a country's stocks to foreigners, and one minus the ratio is a measure of foreign ownership restrictions (Table 1, Row 9). This measure can be seen as an extension of the liberalization analysis of Bekaert and Harvey (2000) and Henry (2000a). Indeed, the initial relaxation of controls shown by the Edison-Warnock measure corresponds quite well with the Bekaert-Harvey liberalization date. ${ }^{14}$ This new measure provides additional information, giving an indication of the extent of the liberalization and its evolution over time. It shows that international financial liberalizations can be gradual — a point also made in

http: //faculty-gsb.stanford.edu/henry/personal/homepage.htm.

${ }^{14}$ The liberalization dates in Henry (2000a) are somewhat earlier for some emerging markets, primarily those for which country funds existed in the mid-1980s. 
Bekaert and Harvey (1995) — which would argue against the use of an event study approach or structural break analysis.

\section{B. Quantitative Measures}

An alternative to the practice discussed above, of constructing indicators from published regulations, is to derive quantitative measures of the limits placed on capital account transactions from the values of economic variables. There are three different sets of variables that researchers have considered in this vein: national savings rates paired with national investment rates, interest rate differentials, and international capital flows. While, at first blush, it may seem preferable to use actual performance rather than published regulations in order to gauge the restrictiveness of capital controls, we will see that, as with

rules-based measures, there are conceptual and practical challenges associated with the use of these quantitative measures.

To the best of our knowledge, neither a comparison of national savings rates with national investment rates nor interest rate differentials has been used in studying the effects of capital account liberalization on long-run economic growth. There have been some recent efforts to use actual capital flows to estimate the effects of capital account restrictiveness on growth. Despite the limited use of these measures in analyzing the links between capital account liberalization and growth, we discuss each of these three sets of measures since they have been used to gauge the extent of capital account restrictions across countries and across time periods. 
Feldstein and Horioka (1980) published a study that was quite influential due, in part, to the fact that it was one of the first efforts to quantitatively measure the extent of capital mobility across a broad range of countries. They analyzed the behavior of savings and investment in a number of countries to measure the "true" degree of capital mobility, arguing that the degree of correlation between the two series was a good indicator of impediments to capital movements. In any particular year, savings matches investment in a country with stringent capital account restrictions while there need not be a link between savings and investment in a country with free capital mobility. Feldstein and Horioka found that, over the period 1960-1974, as well as over the three five-year sub-periods making up this 15-year period, average savings rates and average investment rates were highly positively correlated. Based on this finding, they concluded that there were significant impediments to capital movements. $^{15}$

But this conclusion has been criticized since the savings and investment rates of a country may be highly correlated, even if that country has no restrictions on international capital flows. For example, Obstfeld (1986) shows that, even with perfect capital mobility, savings and investment may be highly correlated just because of the types of shocks hitting an economy. Obstfeld also demonstrated that the savings-investment correlations were higher for large countries than for small countries, a result one would expect to find if there was free capital mobility and outcomes in large countries influenced worldwide economic conditions. Furthermore, Obstfeld documents a reduction in savings-investment correlations

\footnotetext{
${ }^{15}$ Montiel (1996) used the Feldstein-Horioka method to assess capital mobility by using results of the industrial countries as a benchmark to assess the degree of capital mobility for emerging markets.
} 
in the post-1973 period. A different criticism of Feldstein and Horioka's conclusions concerning the extent of capital mobility based on savings-investment correlations comes from Bayoumi (1990) who shows that this correlation may just reflect efforts by governments to target the current account.

Another set of quantitative measures of capital mobility includes onshore-offshore interest rate differentials and deviations from covered interest rate parity. Unlike stock market returns or other quantitative measures, short-term interest rates can be analyzed without first transforming them in model-specific ways. However, data availability restricts this method to a limited number of countries.

Recently, efforts have been made to gauge the extent of capital mobility through the use of actual capital inflows and outflows, either as a percentage of GDP (Kraay 1998) or, as in Lane and Milesi-Ferretti (forthcoming), by using an annual measure of portfolio and direct investment assets and liabilities as a percent of GDP as a long-run indicator of financial openness (see IMF, 2001, Chanda, 2001, and O’Donnell, 2001). These measures are analogous to measures of trade openness, and can be thought of in a similar manner. For example, like the level of trade openness, which is typically calculated as the sum of imports and exports over GDP, the Lane and Milesi-Ferretti measure is a good indicator of openness at a point in time. But both the Lane and Milesi-Ferretti measure, and that of Kraay, may fluctuate from year-to-year since capital flows are endogenous and there can be large valuation adjustments due to, say, a large swing in equity values (Eichengreen 2001). However, changes in these measures over longer periods are likely to be indicative of changes in openness. In the subsequent section, this stock measure will be referred to as the openness measure. 


\section{Comparisons of Rules-Based and Quantitative Measures of Capital Account Liberalization $^{16}$}

We would hope to find that a measure of capital account restrictiveness based on published regulations and rules is correlated with one that reflects the actual behavior of capital flows. Figure 1 offers some evidence that enables us to judge the correspondence between these two types of measures. This figure includes the time series of a rule-based measure, related to the restrictions on capital flows as reported to the IMF by national authorities, as well as a measure of capital account openness based on the estimated stocks of gross foreign assets and liabilities as a ratio of GDP.

Figure 1 shows that both the rules-based and the quantitative measures indicate that capital accounts in industrial countries have become considerably less restricted over time. A particularly rapid decline in controls occurred during the 1980s, when the members of the European Community (now called the European Union) liberalized capital controls. Following this, there was a dramatic rise in cross-border capital flows. Among industrial countries, Canada, the Netherlands, Switzerland, and the United Kingdom appear to have the most unfettered international capital flows, based on the estimated stocks of gross foreign assets and liabilities as a percent of national income.

In developing countries, the story is more complex. In general, both measures suggest a less dramatic shift toward liberalization and openness than in industrial countries. For the developing countries as a whole, the rules-based restriction measure suggests that, after a period of liberalization in the 1970s, the trend toward openness reversed in the 1980s.

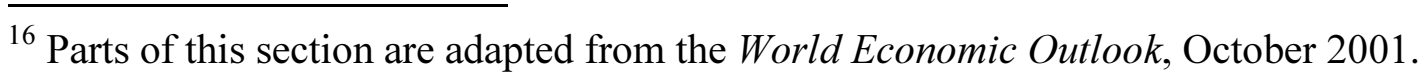


Liberalization resumed in the early 1990 s, but the pace has been relatively slow; the rulesbased measure indicates that the current level of the indicator on average is only at the same level as it was in the late 1970s. By comparison, the capital account openness measure based on the estimated stocks of gross foreign assets and liabilities as a ratio of GDP shows a modest decline in openness to capital flows during the early 1970s, followed by a moderate increase in the 1980s, which accelerated sharply in the early 1990s.

\section{Efficacy of Capital Account Controls}

Some of the rules-based indicators discussed above attempt to distinguish between the intensity with which capital account restrictions are imposed. But rules-based measures focus on de jure restrictions rather than the de facto efficacy of controls. Obviously, it is easier to determine whether laws controlling capital flows are on the books than whether these laws are enforced or, if they are enforced, whether they effectively stem the flow of capital that would otherwise be moving into or out of a country.

Various episodes suggest that capital controls have, at best, a temporary effect on stemming capital inflows or outflows. For example, Spain attempted to use capital controls to shield itself from the disruptions in the European Monetary System in September 1992 but the peseta was devalued in November anyway. Capital controls on inflows in Colombia (1993-1998) and Brazil (1993-1997) did not prevent the continued appreciation of their currencies. In Brazil, the presence of sophisticated financial institutions enabled people to get around controls. Likewise, the much-heralded controls on capital inflows to Chile, which took the form of unremunerated reserve requirements (URR), lost their effectiveness as people found loopholes that enabled them to avoid these regulations. Capital controls in 
Thailand and Malaysia may have altered the maturity structure of capital inflows, though capital controls did not insulate the Thai baht from the consequences of speculative pressures in $1997 .{ }^{17}$

If, in fact, capital controls are generally ridden with holes and are not efficacious, then we would not expect to find a strong link between capital account liberalization and any measures of economic performance, all else equal. We next turn to a review of empirical analyses of whether or not capital account liberalization is significantly associated with economic growth.

\section{REVIEW OF LITERATURE ON CAPITAL ACCOUNT LIBERALIZATION AND GROWTH}

Economic theory suggests a number of benefits that may accompany capital account liberalization. Open capital accounts can foster a more efficient allocation of resources, provide opportunities for risk diversification and help promote financial development. But there is also a good deal of skepticism concerning the benefits of capital mobility.

While analysis of the costs of capital account liberalization have been limited, there is a large and growing literature that tests the potential benefits of capital account liberalization through its influence on long-run growth and development, by directly investigating the empirical relationship between capital account liberalization and economic growth. Almost

\footnotetext{
${ }^{17}$ Efforts to quantify the effects of capital controls include Giavazzi and Giovannini (1989) who looked at EMS members in the 1980s, and Edwards (1999) and De Gregorio, Edwards, and Valdes (2000) who considered the effects of Chile's unremunerated reserve requirements. More recently Edison and Reinhart (2001) and Kaplan and Rodrik (2001) have examined the effectiveness of Malaysian capital controls, which were applied during the Asian financial crisis.
} 
all of these studies augment a basic growth model that includes variables such as the level of schooling, investment, population growth, and the level of GDP in the initial year with a measure of capital account liberalization.

Table 6 presents an overview of these studies of the effects of capital account liberalization on growth. Each row of this table presents information on one study. The columns of the table offer information on the country coverage, the indicator of liberalization, the estimation techniques and the general result of the studies.

The information presented in Table 6 indicates that there is a wide divergence in results across studies. This may reflect a number of differences in these studies. First, the country coverage is different across studies, with some authors analyzing industrial countries, others developing countries, and others a mixture of the two. Second, there are differences in the sample period, which may be particularly important for developing countries given the recent nature of many capital account liberalizations. Third, the applied methodology (crosssectional, time series, or panel) and the estimation technique (ordinary least squares, instrumental variables, or generalized method of moments) differ across studies.

In addition to particular differences across studies, there are some general drawbacks with the literature that analyzes the relationship between liberalization and growth. As noted in the previous section, rules-based measures of capital account controls and liberalization used in the bulk of these studies are relatively crude. However, it should be noted that the previous section has also shown that various measures offer a broadly consistent picture of the time series and cross sectional behavior of capital account liberalization. On a more conceptual note, while capital account liberalization is often treated as exogenous to the growth process, in practice countries with particular growth experiences or at particular 
levels of development may be more prone to liberalize their capital accounts, implying the potential for reverse causality. ${ }^{18}$ But the authors of many of these studies recognize this potential shortcoming and attempt to address it through the use of instrumental variable estimation.

We next survey these studies in more detail, beginning with work that offers support for the hypothesis that capital account liberalization promotes economic growth, and then turning to studies that cast some doubt on this relationship.

\section{A. Supporting Evidence of Capital Account Liberalization on Growth}

Quinn (1997) is one of the first studies to identify a positive result between capital account liberalization and growth. Quinn augments the set of variables included in a standard growth regression with either a variable representing his indicator of the change in financial openness (described above) or the change in a broader measure of openness. ${ }^{19}$ The change in the financial openness variable and the change in the broader openness variable are calculated by subtracting the 1958 value of the index from its 1988 value. Quinn's empirical estimates suggest that the change in capital account liberalization has a strongly significant effect on the growth in real GDP per capita in his cross section of 58 countries over the period 1960 to 1989. It is hard to disentangle the separate effects of financial openness and a

\footnotetext{
${ }^{18}$ For example, a country with weak economic performance might choose to adopt capital controls and there is a danger in such a case to interpret incorrectly that the country's low growth depends on those controls.

${ }^{19}$ The base regression includes also initial GDP per capita, investment as a share of GDP, population growth and secondary-school enrollment rates.
} 
broader measure of openness in Quinn's results because he does not include a regression with both of these indicators and, therefore, to the extent that the change in financial openness is correlated with the change in the openness of trade in goods and services, the finding of a significant effect of the change in capital account liberalization on growth may reflect the correlation of changes in restrictions on the capital account and the current account.

Klein and Olivei (2000) find a positive effect of capital account liberalization on growth among industrial countries, but they do not find evidence that capital account liberalization promotes growth in non-industrial countries. This study follows a slightly different strategy from other research in this area by first focusing on the role of capital account liberalization on financial development and then considering the effect of financial development on growth. Klein and Olivei regress the capital account liberalization indicator Share described above (along with other standard regressors) on the change in financial depth over the period 1986 to 1995 . They find a significant effect of capital account liberalization on the change in financial depth in the cross section of 82 developed and developing nations. This significant result seems to be due to the presence of the OECD countries in the sample. Klein and Olivei show that capital account liberalization significantly affects the change in financial depth in a sample consisting of the 20 OECD countries, but not in a sample of the non-OECD countries, nor in a narrower non-OECD sample of 18 Latin American countries, a group that had a relatively high incidence of capital account liberalizations. They also estimate a growth model that includes the change in financial depth as regressor and find that financial development is significant determinant of growth per capita. Klein and Olivei conclude that the beneficial effects of capital account liberalization, at least with respect to promoting financial depth, are achieved only in an 
environment in which there is a constellation of other institutions that can usefully support the changes brought about by the free flow of capital. Bailliu (2000) also finds that capital account liberalization spurs growth by promoting financial development.

This conjecture, that the growth effects of capital account liberalization depend upon the level of development of an economy, is supported by the results presented in Edwards (2001). Edwards finds that both the Quinn level and the $\Delta$ Quinn variables are significantly associated with growth in per capita income in the 1980s for a sample of about 60 countries, though his results are not robust when he instead uses Share. Edwards estimates regressions using weighted least squares, with the weights representing national income in $1985 . \mathrm{He}$ includes both the capital account liberalization variables and an interactive term representing the product of the variables and the logarithm of income per capita in 1980. His estimates show a negative coefficient on capital account openness and a positive coefficient on the openness-income interactive term. This suggests that capital account openness detracts from growth for countries at lower levels of income but promotes growth in industrial countries and in the richer emerging market countries.

Edwards' methodology is scrutinized in Arteta, Eichengreen, and Wyplosz (2001). They question why Edwards obtains such strong results while other studies (cited below) fail to find any significant effect of capital account liberalization on growth. They point to a number of potential reasons for this discrepancy. They question whether Quinn's measures, representing capital account openness in 1973 and 1988 only, is appropriate for the period Edwards studies. They also note that weighting observations by 1985 per capita GDP means that rich countries have much more influence in the regressions than do poor countries. There are also questions raised concerning the exogeneity of instruments used for capital account 
liberalization and the exclusion of other potentially relevant measures of openness, such as the openness of the current account, which may be correlated with capital account openness. Estimates by Arteta, Eichengreen, and Wyplosz suggest that Edwards' results may be sensitive to a variety of factors and, therefore, they conclude that there is little evidence that capital account liberalization has more favorable effects in high-income and middle-income countries than in poorer developing countries.

But Arteta, Eichengreen, and Wyplosz do find some support for differences in the effect of capital account liberalization across countries, depending upon the degree of macroeconomic stability. They introduce two capital account interaction terms, multiplying the Quinn openness measure by both the Sachs-Warner (1995) openness measure and the black-market premium. They find that the interaction term representing the product of capital account openness and the black market premium is significant but the other interaction term, representing the product of the Sachs-Warner openness measure and capital account openness, is not significant. They interpret this to mean that countries that open their capital accounts grow faster, but only if they first eliminate the black market premium.

Bekaert, Harvey, and Lundblad (2001) (henceforth BHL) examine the impact of stock market liberalization on economic growth. As previous researchers have done, they begin their analysis by augmenting the standard set of growth model variables with their variable indicating stock market liberalization. To maximize the time-series content in their regression, they use a moving average panel data method. This means that they create overlapping data and therefore have to deal with the resulting moving average error component by adjusting their standard errors. In general, BHL find that financial liberalization leads to a 1 percent increase in annual per capital GDP growth over a five-year 
period and that this effect is statistically significant. BHL investigate the robustness of this result with respect to alternative sets of liberalization dates, different country groupings, and different time horizons for measuring economic growth. These results, along with those of Quinn, appear to be the strongest evidence supporting the hypothesis that capital account liberalization promotes growth among developing countries.

Following a slightly different tact, O’Donnell (2001) examines the impact of capital account liberalization using both IMF rules-based measure and a quantitative based measure of financial openness. Using a rather standard setup, he finds that the rules-based measure tends to be too coarse an indicator of the degree of capital account liberalization as it does not take account the nature of different types of controls. However, using the quantitative measure, he finds that capital account liberalization does seem to speed up economic growth. However, like other researchers he finds that the benefits to all countries are not equal. This difference in impact was also echoed in Chanda (2001). He suggests that the impact may vary with the level of ethnic and linguistic heterogeneity in the society, a proxy for the number of interest groups. In particular, he finds that capital controls lead to greater inefficiencies and lower growth among countries with a high degree of ethnic and linguistic heterogeneity.

\section{B. Studies Not Supporting the Hypothesis that Liberalization Promotes Growth}

Several studies have found no correlation between openness and growth. In fact, one

of the first efforts to determine whether capital account liberalization promotes growth using a cross-section of countries was Grilli and Milesi-Ferretti (1995), although this was not the main focus of their paper. This study considers average growth of per capita income for five 
nonoverlapping five-year periods between 1966 and 1989. Their sample includes 61 countries although, with 181 observations in one set of regressions and 238 in another, not every country appears in each of the five sub-periods. They regress five-year growth rates on Share and comparable measures that capture the presence of current account controls (CurrAcct) and a multiple exchange rate system (MultEx) from Exchange Arrangements and Exchange Restrictions. In addition they include variables such as initial income, political variables and the level of schooling. The three variables Share, CurrAcct, and MultEx enter as predicted values from instrumental variable regressions using lagged values as the instruments. Their results do not support the hypothesis that capital account liberalization promotes growth. In some cases, capital account controls enter with a positive sign (that is, Share enters negatively) while the indicator of current account controls sometime enters with a negative sign (CurrAcct is positive). ${ }^{20}$

Rodrik (1998), in a widely cited paper, also casts doubt on the effect of capital account liberalization on growth. In a sample that includes almost 100 countries, developing as well as developed, he finds no significant effect of capital account liberalization, as measured by Share, on the percentage change in real income per capita over the period 1975 to 1989 in growth regressions that also include initial per capita income, initial secondaryschool enrollment rate, an index of the quality of governmental institutions and regional dummy variables. Likewise, he finds no relationship between capital account liberalization and investment-to-income, nor between capital account liberalization and inflation. Eichengreen (2001) offers several possible reasons for the differences in the results between

\footnotetext{
${ }^{20}$ See their Table 4, p. 537.
} 
the Quinn and Rodrik papers, including the fact that Quinn's sample includes fewer developing countries than Rodrik, the smaller proportion of years in Quinn's study representing the "lost decade" of the 1980s and differences in the capital account indicator. The regressions presented in the next section allow us to explore the role of these potential sources of the differences in the two studies.

Kraay (1998) also finds no significant relationship, using a variety of measures of capital account openness, including Share, Quinn's capital account openness indicator (in levels, with values from 0 to 4), and a measure based on actual net capital flows. Each of these measures is associated with a different sample size. His regressions take the form of cross sections, with one observation per country, where the dependent variable is the growth in output between 1985 and 1997. He uses both OLS and an approach in which the capital account liberalization variables are instrumented by their own past values. He fails to find a significant effect of Share or the Quinn indicator on growth, but, when these indicators are interacted with the average balance of the financial account (from the balance of payments statistics), he does find some significant effects.

\section{EMPIRICAL INVESTIGATION}

The literature reviewed in the previous section offers a diverse set of results concerning the effect of capital account liberalization on growth. In this section, in an effort to reconcile some of the differences in the literature, we estimate the effects of a variety of measures of capital account liberalization on economic growth. We present estimates of 
growth regressions that augment a standard economic growth mode $^{21}$ with different indicators of capital account openness or stock market liberalization, but otherwise use a common set of regressors, a common regressand, and draw observations from the same time period. ${ }^{22}$ For comparability, we use a single dataset, the Klein and Olivei (2000).

\section{A. The Basic Growth Model and the Impact of Capital Account Liberalizaton}

The regressand in all of the estimates presented in this section is the growth in real per capita income over the period 1976 to $1995\left(\Delta \ln Y_{76-95}\right)$. The control variables used in the growth model include the logarithm of real per capita income in $1976\left(\ln \left(\mathrm{Y}_{1976}\right)\right)$, the logarithm of secondary school enrollment rate in $1976(\ln ($ Educ.)), the average investment to GDP ratio for the years 1974 to 1978 (Invest.74-78), the population growth rate from 1976 to 1995 ( $\triangle$ Pop. $.76-95$ ) and a dummy variable for countries in sub-Saharan Africa (Africa). Column 1 of Table 7 shows the results of a growth regression using these regressors for a sample of 89 countries. Each of the coefficients in the regression are significant at the 95 percent level of confidence or better, but for the coefficient on the average investment to GDP ratio.

We use three different indicators of capital account liberalization. First, as discussed in Section II, Share $76-95$ represents the proportion of years in the period 1976 to 1995 that a country had open capital accounts, based on information from line E.2 of the IMF's Annual

\footnotetext{
${ }^{21}$ See for example Barro and Sala-I-Martin (1995) and Levine and Renelt (1992).

${ }^{22}$ There remain, however, differences in the samples across regressions due to differences in the set of countries covered by each indicator of capital market openness. Below we discuss the sensitivity of results to the use of different samples of countries.
} 
Report on Exchange Arrangements and Exchange Restrictions. Second, we use the 0 to 4 measure of capital account openness in 1982 from Quinn (1997), which we denote as Quinn $_{82 .}$. As discussed above, Quinn used the change in the value of his indicator and, therefore, we also present a regression in which we use the difference in the value of the 0 to 4 measure of capital account openness between 1973 and 1988, $\Delta$ Quinn ${ }_{73}-88 .{ }^{23}$ Third, we use the dates of stock market liberalization from Bekaert, Harvey and Lundblad (2001) to calculate the proportion of years between 1980 (when the data are first available) and 1995 that a country had a liberalized stock market. This variable, $B H L_{80-95}$, is therefore analogous in its construction to Share $_{76-95}$.

Columns 2 through 5 of Table 7 present growth regressions in which the standard growth model presented in Column 1 is augmented with, in turn, each of these indicators of capital account liberalization. The results in this column generally support the hypothesis that liberalization of the capital account or of the equity market promotes growth, ceteris paribus. The coefficients on Share ${ }_{76-95}$, Quinn $n_{82}$, and $B H L_{80-95}$ each have a p-value of less than 0.01 . The coefficient on $\Delta$ Quinn $_{73}-88$ is positive but insignificant (the p-value is 0.50 ), a result at odds with those presented in Quinn (1997) in which the estimated coefficient on the change in the capital account openness measure is positive and significant. ${ }^{24}$

${ }^{23}$ Recall that Quinn's measure of capital account openness is available only for the years 1973, 1982 and 1988 for non-OECD countries.

${ }^{24}$ In a regression that differs from the one presented in Column 3 only by the use of the Quinn indicator of capital account openness in 1973 rather than its value in 1982, the coefficient on the Quinn $0-4$ indicator of capital account openness has a value of 0.09 with an associated p-value of 0.08. We have also run regressions similar to the one presented in Column 4 but with the difference in the Quinn indicator of capital account openness between 1982 and

(continued...) 
A question that arises when considering the results in Columns 2 through 5 of Table 7 is whether there is an upward bias on the coefficients on liberalization because of reverse causality; perhaps the countries that are most likely to have liberalized their capital accounts are the ones that grew most quickly during the relevant period. To address this question, we present, in Columns 6 through 8 of Table 7, two-stage regressions that instrument for the values of the liberalization measures. The instruments that we use include government consumption as proportion of GDP in 1976, imports as proportion of GDP in 1976, a dummy variable for Latin American countries and another dummy variable for East Asian countries. In addition, for Share $76-95$ and for $B H L_{80-95}$ we use, as an instrument, the 0 or 1 value of the capital account openness measure for 1973 from the IMF's Annual Report on Exchange Arrangements and Exchange Restrictions while for the Quinn 0 to 4 measure of capital account openness in 1982 we use, as an instrument, the 1973 value of Quinn's openness measure.

The results presented in Columns 6 through 8 of Table 7 indicate that, in all three cases, there is not an upward bias on the liberalization measures coefficients when we use OLS estimation since, in each case, the coefficient is larger using instrumental variables than when using OLS. Each of the liberalization coefficients presented in Columns 6 through 8 is significant at the 99 percent level of confidence or better. The adjusted $\mathrm{R}^{2}$ for the first stage regression (which is not reported in the table) is 0.61 for Share $76-95,0.69$ for Quinn $_{82}$, and 0.59 for $B H L_{80-95}$.

1988, as well as between 1973 and 1982. The coefficients on the change in the capital account indicator in these regressions are not significant at standard levels. 
The results of a formal test concerning the possible endogeneity of the capital account openness variables are presented in Table 7 in the row labeled "DM p-value." The statistics in this row are obtained using the artificial regression technique discussed in Davidson and MacKinnon (1989). ${ }^{25}$ As shown in this row, the p-values on the coefficients on the instrumented regressors are 0.13 in the regression using Share $_{76-95}, 0.52$ in the regression using Quinn ${ }_{82}$, and 0.01 in the regression using $B H L_{80-95}$. Therefore, estimates using OLS are not plagued by a significant (at the 10 percent level) problem with respect to consistency because of the endogeneity of the capital account openness variables in the regressions using either Share $76-95$, or Quinn 82 . There is evidence, however, that supports the use of instrumental variables in the regression using $B H L_{80-95}$. In the remainder of this section, we present results of the Davidson and MacKinnon test for all regressions and, where appropriate as indicated by this test, we estimate the regressions using instrumental variables rather than OLS. ${ }^{26}$

\footnotetext{
${ }^{25}$ The "artificial regression" is one in which the OLS regression is augmented with the instrumented values of the potentially endogenous variable. Under the null hypothesis that the OLS estimates of the coefficients of the regression are consistent (and assuming that the instrumental variable estimates are consistent), the coefficient on the instrumented regressor is asymptotically equal to zero. Therefore, if the coefficient on the instrumented variable in the augmented artificial regression is insignificant, we cannot reject the hypothesis that OLS provides us with consistent estimators. We employ this test and report the p-value of the coefficient on the instrumented regressor in the row labeled "DM p-value" in Table 7.

${ }^{26}$ In the regressions reported in Tables 8 and 9 there are several capital account openness variables in each regression since we allow for different coefficients across regions. In these cases, the DM test is an F-test of the joint significance of all the capital account openness variables used in the regression.
} 


\section{B. The Robustness of the Results}

An issue that arises in the literature surveyed above is whether the effect of capital account liberalization differs between industrial counties and developing countries. We investigate this in Columns 1 through 3 of Table 8 by reporting separate slope coefficients for industrial and developing countries (countries are classified as industrial if they were members of the O.E.C.D. in 1986). ${ }^{27}$ These results show that the estimated effect on economic growth of capital account openness or stock market liberalization is larger in developing countries than in industrial countries. ${ }^{28}$ For developing countries, coefficients on both measures of capital account openness, Share $76-95$, and Quinn 82 , are significant at better than the 99 percent level. In addition, the coefficient on Quinn $_{82}$ for industrial countries is also significant at better than the 99 percent level. The results for stock market liberalization, estimated using instrumental variables, also indicate strongly significant effects for both developing countries and industrial countries.

All three regressions reported in Columns 1 through 3 of Table 8 show a significant effect of capital account liberalization on growth among non-O.E.C.D. countries but differ in the reported effect among O.E.C.D. countries. One possible source of this difference is the

${ }^{27}$ These results are obtained by including in the regressions both the measures of liberalization and the product of the respective measure and a dummy variable that takes the value of 1 for the 20 countries in the sample that were members of the O.E.C.D. in 1986. These countries include Australia, Austria, Belgium, Canada, Denmark, Finland, France, Greece, Iceland, Ireland, Italy, Japan, the Netherlands, New Zealand, Norway, Portugal, Spain, Sweden, the United Kingdom, and the United States.

${ }^{28}$ There is a statistically significant difference (at the 92 percent level) between the estimated coefficients for developing and industrial countries for $B H L_{80-95}$, but not at the 90 percent level for Share ${ }_{76-95}$, nor for Quinn 82 . 
samples used in each regression. We ran regressions using Share $76-95$, allowing for different effects across industrial and developing countries, using the subsamples employed when using either Quinn $_{82}$ or $B H L_{80-95}$ as a regressor. The Quinn 82 sample of 52 countries yields estimates of the effect of capital account liberalization on growth of 0.17 for industrial countries and 0.34 for developing countries, with associated p-values of 0.20 and 0.06 , respectively. These point estimates are both a bit smaller and somewhat less significant than those obtained with the full sample of 89 countries. With the sample of 82 countries used in the estimation of the effects of $B H L_{80-95}$ on growth, the estimated effect of Share $e_{76-95}$ on growth for industrial countries is 0.20 (with a p-value of 0.07 ) and for developing countries it is 0.32 (with a p-value of 0.07 ). This suggests that differences across indicators due to differences in samples necessitated by data availability are not pronounced.

The discussion in Section II shows that the majority of cases of capital account liberalization and stock market liberalization outside of the OECD occurred among countries in Latin America and East Asia. Columns 4 through 6 of Table 8 continue our investigation of differential effects of liberalization across sets of countries by allowing for separate slopes across countries in Latin America, countries in East Asia, OECD member countries, and all other countries. These estimates suggest that the largest and most significant effect of capital account liberalization on growth occurred among East Asian countries. For each of the three variables, the effect of liberalization on growth in East Asia is significant at greater than the 99 percent level of confidence. In other regions, there is less evidence of a significant effect of capital account liberalization on growth. This effect is significant for the OECD countries in this set of regressions only when using the Quinn $n_{82}$ indicator of capital account openness. 
Capital account liberalization is estimated to have a negative effect on growth among Latin American countries when using the Share $76-95$ indicator.

Differences in the effect of capital account liberalization on growth across the set of industrial and developing countries are present in some of the research discussed in the literature review above. But, in those papers, (such as Klein and Olivei (2000) and Edwards (2001)), capital account liberalization is usually found to have a more significant effect in promoting growth in industrial countries. The results of this paper, however, suggest that open capital accounts and liberalized stock markets have a significant effect on growth among East Asian countries, but there is less consistent evidence of these effects elsewhere, even among industrial countries.

One concern with the results presented in Tables 7 and 8 is that it is possible that capital account liberalization is really just a proxy for some other characteristic of the countries in the sample. Rodrik (1998) argues that capital account liberalization measures serve as a proxy for the quality of government. We investigate this possibility in Table 9 . This specifications used in the regressions reported in this table differ from those used in Table 8 only by the inclusion of a measure of government reputation. This measure, from Knack and Keefer (1995), draws on information from various volumes of the International Country Risk Guide. The variable potentially ranges from 1 to 10 , with larger values indicating that a government is less likely to repudiate contracts. For most countries, the variable reflects reputation in 1982.

The results in Table 9 support the importance of government reputation as a determinant of growth but do not support the claim that capital account liberalization merely serves as a proxy for government reputation. In each of the six regressions, the coefficient on 
government reputation is significant at better than the 99 percent level of confidence. While it is true that the neither the coefficient on Quinn $_{82}$ for industrial nor for developing countries is significant in Column 2 (in contrast to the results presented in Table 8), and that the coefficient on Share ${ }_{76-95}$ for developing countries has a p-value of 0.07 as compared to 0.01 when government reputation is not included as a regressor (Column 1 in each table), the coefficient on $B H L_{80-95}$ for developing countries reported in Column 3 as well as each of the coefficients on the capital account openness or stock market liberalization variables for East Asia in Columns 4 through 6 continue to be significant at better than the 99 percent level of confidence.

A careful comparison of Tables 8 and 9 shows that the introduction of the government reputation variable reduces the number of observations in the regressions using Share $86-95$ by about one-fifth, from 89 to 71 . This is part of the reason for the differences in the results concerning the coefficients on capital account liberalization in Columns 1 and 4 across these two tables. A regression with a specification like that in Column 1 of Table 8 that uses the sample of 71 countries that have non-missing values of the government repudiation variable (i.e. the sample used in Columns 1 and 4 of Table 9) has estimated coefficients of 0.17 (with a p-value of 0.09 ) for industrial countries and 0.34 (with a p-value of 0.06) for developing countries. These point estimates are lower than those reported in Column 1 of Table 8 and these coefficients are less significant in the more restricted sample. When allowing for different estimates across regions of non-O.E.C.D. countries, the main difference in the value and pattern of significance between the samples of 71 and 89 countries is that the former yields a significant effect of capital account liberalization on growth for non-O.E.C.D. countries outside of Latin America and East Asia; the estimated 
coefficient on Share $86-95$ for this group of countries is 1.13 , with a standard error of 0.47 (and therefore a p-value of 0.02). The pattern of significance of the effects of stock market liberalization on growth presented in Column 6 of Table 8 do not change very much if we restrict the sample to the 68 countries that have non-missing observations for both the government reputation variable and $B H L_{80-95}$. Therefore, the loss of significance of the coefficient on $B H L_{80-95}$ for non-O.E.C.D. countries outside of East Asia and Latin America is likely due to the correlation of government reputation with $B H L_{80-95}$ for these countries. But note that the coefficient on the $B H L_{80-95}$ for East Asian countries retains its significance in the results presented in Column 6 of Table 9.

\section{CONCLUSION}

The consequences and desirability of capital account liberalization among developing countries is likely to remain a topic of debate for the foreseeable future. People on one side of this debate will maintain those countries that open up to financial flows will set the stage for more rapid development. Those on the other side will question the advantages actually conferred by capital account liberalization and, furthermore, will argue that countries become more vulnerable to financial disruptions not of their own making when their governments relinquish control over the inflow and outflow of capital.

In this paper we have surveyed what current research is able to tell us about the consequences of capital account liberalization. We point out that, while industrial countries have largely liberalized their capital accounts, and there has been some movement towards more widespread capital account liberalization among developing countries, the majority of developing countries retain controls over capital flows. The evidence on the effects of this 
are somewhat mixed. We have shown that empirical evidence presented in existing research does not strongly point towards a general result concerning the consequences of capital account liberalization. There is mixed evidence that capital account liberalization promotes long-run economic growth. Our own regression results suggest that these effects are most pronounced among countries in East Asia. Other research surveyed in this paper, however, suggests a more pronounced effect of capital account liberalization among industrial countries than among a more broadly defined set of developing countries.

Given the importance of this topic, the lack of a clear consensus in the literature, and, perhaps most importantly, the fact that undertaking capital account liberalization is more easily achieved than many other policies advocated to governments of developing countries, it is very likely literature on the topic surveyed in this paper will continue to expand. The concern that this research is hampered by a strong set of variables reflecting capital account openness should be somewhat allayed by the statistics presented in this paper showing a common cross-country picture of capital account openness regardless of the (admittedly imperfect) indicators that are employed. But, as better indicators are developed, and as we obtain a longer time series that encompasses a wider range of experiences, we would expect that our understanding of this important topic will be refined. 


\section{REFERENCES}

Ahearne, Alan, William Griever, and Francis Warnock, 2000, "Information Costs and Home Bias: An Analysis of U.S. Holdings of Foreign Equities," International Finance Discussion Paper 691, (Washington: Board of Governors of the Federal Reserve System).

Arteta, Carlos, Barry Eichengreen and Charles Wyplosz, 2001, "On the Growth Effects of Capital Account Liberalization," (unpublished; Berkeley, California: University of California).

Bailliu, Jeannine, 2000, "Private Capital Flows, Financial Development, and Economic Growth in Developing Countries," Bank of Canada Working Paper No. 2000-15, (Ontario, Canada, Bank of Canada).

Barro, Robert, and Xavier Sala-i, Martin, 1995, "Economic Growths, " (Cambridge, Massachusetts: MIT Press).

Bayoumi, Tamim, 1990, "Saving-Investment Correlations," IMF Staff Papers, Vol. 37, No. 2 (June), pp. 360-86.

Bekaert, Geert, 1995, "Market Integration and Investment Barriers in Emerging Equity Markets," World Bank Economic Review, Vol. 9, pp. 75-107.

— Finance, Vol. 50, pp. 403-44.

- and Campbell Harvey, 2000, "Foreign Speculators and Emerging Equity Markets," Journal of Finance, Vol. 55 (April), pp. 565-613.

— forthcoming, Journal of Financial Economics.

Bekaert, Geert, Campbell Harvey, and Christian Lundblad, 2001, "Does Financial Liberalization Spur Growth?” NBER Working Paper No. 8245 (Cambridge, Massachusetts: National Bureau of Economic Research).

Bhagwati, Jagdish, 1998, "The Capital Myth: The Difference Between Trade in Widgets and Trade in Dollars," Foreign Affairs, Vol. 77, pp. 7-12.

Chanda, Areendam, 2001, "The Influence of Capital Controls on Long-Run Growth: Where and How Much?” (unpublished; Providence, Rhode Island: Brown University). 
Davidson, Russell and James G. MacKinnon, "Testing for Consistency Using Artificial Regressions," Econometric Theory, vol. 5, pp. $363-384$.

DeGregorio, José, Sebastian Edwards, and Rodrigo O. Valdes, 2000, "Controls on Capital Inflows: Do They Work?" NBER Working Paper No. 7645 (April) (Cambridge, Massachusetts: National Bureau of Economic Research).

Edison, Hali J., and Carmen Reinhart, 2001, "Stopping Hot Money," Journal of Development Economics, Vol. 66, pp 533-53.

Edison, Hali J., and Francis E. Warnock, 2001, "A Simple Measure of the Intensity of Capital Controls," IMF Working Paper 01/180 (Washington: International Monetary Fund).

Edwards, Sebastian, 1999, "How Effective are Capital Controls?" Journal of Economic Perspectives, Fall, Vol. 13, No. 4, pp. 65-84.

— , 2001, "Capital Mobility and Economic Performance: Are Emerging Economies Different?” NBER Working Paper No. 8076 (Cambridge, Massachusetts: National Bureau of Economic Research).

Eichengreen, Barry, 2001, "Capital Account Liberalization: What Do Cross-Country Studies Tell Us?"' (unpublished; Berkeley, California: University of California.

Feldstein, Martin, and Charles Horioka, 1980, "Domestic Saving and International Capital Flows," The Economic Journal, Vol. 90, No. 358, pp. 314-29.

Giavazzi, Francesco, and Alberto Giovannini, 1989, Limiting Exchange Rate Flexibility: The European Monetary System, (Cambridge, Massachusetts: MIT Press).

Grilli, Vittorio, and Gian Maria Milesi-Ferretti, 1995, "Economic Effects and Structural Determinants of Capital Controls," IMF Staff Papers, Vol. 42, No. 3, pp. 517-51.

Henry, Peter Blair, 2000a, "Stock Market Liberalization, Economic Reform, and Emerging Market Equity Prices," Journal of Finance, Vol. LV, No. 2 (April), pp. 529-64.

— 2000b, "Do Stock Market Liberalizations Cause Investment Booms?" Journal of Financial Economics, Vol. 58, Nos. 1-2 (October), pp. 301-34.

International Monetary Fund, 2001,. World Economic Outlook, October (Washington: International Monetary Fund).

—_, Annual Report on Exchange Arrangements and Exchange Restrictions, Various Issues, (Washington: International Monetary Fund). 
Kaplan, Ethan, and Dani Rodrik, 2001, "Did the Malaysian Capital Controls Work?” NBER Working Paper No. 8142 (Cambridge, Massachusetts: National Bureau of Economic Research).

Klein, Michael W., and Giovanni Olivei, 2000, "Capital Account Liberalization, Financial Depth and Economic Growth," unpublished; (Boston, Massachusetts: Fletcher School of Law and Diplomacy, Tufts University).

Knack, Stephen, and Philip Keefer, "Institutions and Economic Performance: Cross-Country Tests Using Alternative Institutional Measures," Economics and Politics, vol. 7, 1995, pp.207-27.

Kraay, Aart, 1998, "In Search of the Macroeconomic Effects of Capital Account Liberalization," unpublished; (Washington: The World Bank).

Lane, Phillip, and Gian Maria Milesi-Ferretti, "The External Wealth of Nations: Measures of Foreign Assets and Liabilities for Industrial and Developing Nations," Journal of International Economics, forthcoming.

Levine, Ross, and Sara Zervos, 1998, "Stock Markets, Banks, and Economic Growth," American Economic Review, Vol. 88, (June), pp 537-58.

Levine, Ross, and David Renelt, 1992, "A Sensitivity Analysis of Cross Country Growth Regressions," American Economic Review, pp. 942-63.

Montiel, Peter, 1996, "Managing Economic Policy in the Face of Large Capital Inflows: What Have We Learned?" in Private Capital Flows to Emerging Markets After the Mexican Crisis, ed. by G. Calvo and M. Hochreiter, (Washington: Institute for International Economics), pp 189-218.

Montiel, Peter, and Carmen Reinhart, 1999, "Do Capital Controls and Macroeconomic Policies Influence the Volume and Composition of Capital Flows? Evidence from the 1990s," Journal of International Money and Finance, Vol. 18, No. 4, pp 619-35.

Obstfeld, Maurice, 1986, "Capital Mobility in the World Economy: Theory and Measurement," in Carnegie-Rochester Conference Series on Public Policy, Vol. 24, ed. by K. Brunner and A. Meltzer, (Spring).

O’Donnell, Barry, 2001. "Financial Openness and Economic Performance," (unpublished; Dublin, Ireland: Trinity College).

Quinn, Dennis, 1997, "The Correlates of Change in International Financial Regulation," American Political Science Review, Vol. 91, No. 3, (September), pp. 531-51. 
Rodrik, Dani, 1998, "Who Needs Capital-Account Convertibility?” (February), mimeo; (Cambridge, Massachusetts: Harvard University).

Sachs, Jeffrey, and Andrew Warner, 1995, "Economic Reform and the Process of Global Integration," Brookings Papers on Economic Activity, Vol. 1, pp. 1-118 (Washington: Brookings Institute).

Summers, Lawrence, 2000, "International Financial Crises: Causes, Prevention, and Cures," American Economic Review, Vol. 90, No. 2 (May), pp. 1-16. 
Table 1. Summary of Indicators of Restrictions

\begin{tabular}{|c|c|c|c|c|c|}
\hline Name & Source & Description & Range & Years & Country Coverage \\
\hline 1. IMF & $\begin{array}{l}\text { IMF } \\
A R E A E R \text {, line } \\
\text { E2, various } \\
\text { issues }\end{array}$ & $\begin{array}{l}\text { Constructed as an on/off indicator of the } \\
\text { existence of rules/restrictions that inhibit } \\
\text { cross-border flows. }\end{array}$ & $\begin{array}{l}0 \text { (never restricted) to } \\
1 \text { (always restricted) }\end{array}$ & $\begin{array}{l}1967-1995 \\
\text { after which } \\
\text { format changes }\end{array}$ & $\begin{array}{l}117 \text { countries for years } 1976-95 \\
\text { to } \\
137 \text { countries for years } 1986-95\end{array}$ \\
\hline 2. Share & $\begin{array}{l}\text { AREAER, line } \\
\mathrm{E} 2 \text {, various } \\
\text { issues }\end{array}$ & $\begin{array}{l}\text { Uses IMF measure to create proportion of } \\
\text { years that capital account is judged free of } \\
\text { restrictions. Can be constructed for any range, } \\
1966-95 \text {. }\end{array}$ & $\begin{array}{l}0 \text { (never restricted) to } \\
1 \text { (always restricted) }\end{array}$ & $\begin{array}{l}1967-1995 \\
\text { after which } \\
\text { format change }\end{array}$ & $117(76-95)$ to 137 (86-95) \\
\hline 3. Quinn & Quinn (1997) & $\begin{array}{l}\text { Constructed from narrative descriptions in } \\
A R E A E R \text { regarding capital account } \\
\text { restrictions. }\end{array}$ & $\begin{array}{l}\text { Larger numbers mean less } \\
\text { restricted, more open or } \\
\text { meet agreements. Values in } \\
1 / 2 \text { point increments, } 0 \text { - } 4\end{array}$ & $\begin{array}{l}\text { Full Sample: } \\
\text { 1958, 1973, } \\
1982 \text {, and } 1988 .\end{array}$ & $\begin{array}{c}63 \text { countries of which } 20 \text { are } \\
\text { advanced and } 43 \text { are developing } \\
\text { countries }\end{array}$ \\
\hline 4. Quinn & Quinn (1997) & Difference in Quinn Indicators & $\begin{array}{l}\text { Actual Ranges for Capital } \\
\text { Account } \\
1988-1982 ;-1 \text { to } 2 \\
1988-1973 ;-2 \text { to } 2\end{array}$ & $\begin{array}{l}\text { Construct from } \\
\text { dates above }\end{array}$ & $\begin{array}{l}63 \text { countries } 20 \text { are advanced } \\
\text { and } 43 \text { are developing countries }\end{array}$ \\
\hline 5. OECD-Share & $\begin{array}{l}\text { Code of } \\
\text { Liberalisation } \\
\text { of Capital } \\
\text { Movements }\end{array}$ & $\begin{array}{l}\text { Proportion of the } 11 \text { categories free of } \\
\text { restrictions, averaged over the relevant period. }\end{array}$ & $\begin{array}{l}0 \text { (always restricted) to } \\
1 \text { (never restricted) }\end{array}$ & $\begin{array}{l}1986,1988 \\
1990,1993 \\
1995\end{array}$ & 21 OECD countries \\
\hline 6. $M R$ & $\begin{array}{l}\text { Montiel \& } \\
\text { Reinhart } \\
(1999)\end{array}$ & $\begin{array}{l}\text { Measures the intensity of capital account } \\
\text { restrictions }\end{array}$ & $\begin{array}{l}0 \text { (unrestricted), } \\
1 \text { (mild restrictions), } \\
2 \text { (severe restrictions) }\end{array}$ & $\begin{array}{c}\text { Annual, } 1990- \\
1996\end{array}$ & 15 emerging markets \\
\hline $\begin{array}{l}\text { 7.Levine/Zervos } \\
\text { and Henry }\end{array}$ & $\begin{array}{l}\text { Levine and } \\
\text { Zervos } \\
(1998) \text { and } \\
\text { Henry (2000a } \\
\text { and b) }\end{array}$ & $\begin{array}{l}\text { Dates of stock market liberalizations in } \\
\text { emerging markets. }\end{array}$ & $\begin{array}{l}\text { Constructed as } 0 / 1 \text { dummies } \\
\text { for event studies or Share of } \\
\text { years open for cross-section. }\end{array}$ & $\begin{array}{l}\text { Earliest: May } \\
86 . \\
\text { Latest: Dec. } 91\end{array}$ & 11 emerging markets \\
\hline 8. $B H L$ & $\begin{array}{l}\text { Bekaert } \\
\text { Harvey \& } \\
\text { Lundblad, } \\
2001 \\
\end{array}$ & $\begin{array}{l}\text { Dates of stock market liberalizations in } \\
\text { emerging markets and industrial economies. }\end{array}$ & $\begin{array}{c}\text { Constructed as } 0 / 1 \text { dummies } \\
\text { for event studies or as share } \\
\text { of years open for cross- } \\
\text { section. }\end{array}$ & $\begin{array}{l}\text { Earliest: } 1980 \\
\text { Latest: } 1997\end{array}$ & $\begin{array}{l}95 \text { countries. } 43 \text { had some } \\
\text { experience with financial } \\
\text { liberalization }(25 \text { emerging } \\
\text { market, } 18 \text { OECD) } \\
\end{array}$ \\
\hline 9. $E W$ & $\begin{array}{l}\text { Edison and } \\
\text { Warnock } \\
(2001)\end{array}$ & $\begin{array}{l}\text { One minus the ratio of the IFC investable } \\
\text { index to the IFC global index }\end{array}$ & $\begin{array}{c}\text { Constructed to be between } 0 \\
\text { and } 1\end{array}$ & $\begin{array}{l}\text { Earliest } 1988 \text { to } \\
\text { present }\end{array}$ & 29 emerging markets \\
\hline 11. Capflows & Kraay (1998) & Measure based on actual capital flows & $\begin{array}{c}\text { Constructed as percent of } \\
\text { GDP }\end{array}$ & & All countries with BOP Statistics \\
\hline 12. CapStocks & $\begin{array}{l}\text { Lane and } \\
\text { Milesi- } \\
\text { Ferretti } \\
(2001)\end{array}$ & $\begin{array}{l}\text { Measure based on accumulated or stock of } \\
\text { gross capital flows. }\end{array}$ & $\begin{array}{l}\text { Constructed as percent of } \\
\text { GDP }\end{array}$ & $\begin{array}{c}\text { Earliest } 1970- \\
1998\end{array}$ & $\begin{array}{l}70 \text { countries, mix of advanced } \\
\text { and developing }\end{array}$ \\
\hline
\end{tabular}




\section{Table 2. IMF Capital Account Restriction Measure}

\section{A. Value of Share and Years When Capital Markets Open, 1986 - 1995}

(For countries that had open markets at some point in time, i.e. Share $\neq 0$ )

\begin{tabular}{|c|c|c|c|}
\hline A. Share & Years Open & Industrial Countries & Developing Countries \\
\hline 0.1 & 1995 & Norway & Costa Rica, Niger \\
\hline 0.2 & $1994-95$ & Spain & Trinidad \& Tobago \\
\hline 0.3 & $1993-95$ & Portugal, Sweden & Honduras, Peru \\
\hline 0.4 & $1992-95$ & Ireland & Ecuador \\
\hline 0.5 & $1991-95$ & Finland, Austria & Guatemala \\
\hline 0.6 & $1990-95$ & France, Italy & Uruguay \\
\cline { 2 - 4 } & $1988-92,1995$ & & Bolivia, Indonesia, Malaysia, \\
Panama
\end{tabular}

\section{B. The Evolution of Capital Account Restrictions, 1976-1985}

(For countries that had open markets at some point in time during this Period)

\begin{tabular}{|c|c|c|c|}
\hline Years Open & Industrial Countries & Years Open & Developing Countries \\
\hline $1984-1985$ & Australia, New Zealand & $1980-1981$ & Costa Rica \\
\hline $1978-1985$ & Japan, United Kingdom & $1976-1979$ & Guatemala, Honduras \\
\hline & & $1976-1984$ & Ecuador \\
\hline $1976-1985$ & $\begin{array}{c}\text { Belgium, Canada, Germany, } \\
\text { Netherlands, United States }\end{array}$ & $1976-1985$ & Indonesia, Malaysia \\
\hline
\end{tabular}

Source: IMF AREAER and Klein and Olivei 2001. 
Table 3. Quinn's Indicators of Capital Account Liberalization

\begin{tabular}{|c|c|c|c|c|c|c|}
\hline & \multicolumn{6}{|c|}{ Number of Overall Countries } \\
\hline $\begin{array}{l}\text { Indicator } \\
\text { Value }\end{array}$ & In 1973 & In 1982 & In 1988 & $\begin{array}{c}\text { With no } \\
\text { change in } \\
\text { value } \\
1973-1988\end{array}$ & $\begin{array}{c}\text { With } \\
\text { increase in } \\
\text { value } \\
1973-1988\end{array}$ & $\begin{array}{c}\text { With } \\
\text { decrease in } \\
\text { value } \\
1973-1988\end{array}$ \\
\hline 0 (restricted) & 2 & 1 & 0 & 0 & 2 & - \\
\hline 0.5 & 4 & 5 & 3 & 1 & 3 & 0 \\
\hline 1 & 11 & 9 & 7 & 4 & 6 & 1 \\
\hline 1.5 & 13 & 15 & 14 & 6 & 6 & 1 \\
\hline 2 & 7 & 13 & 9 & 0 & 6 & 1 \\
\hline 2.5 & 7 & 4 & 6 & 2 & 4 & 1 \\
\hline 3 & 9 & 7 & 11 & 2 & 4 & 3 \\
\hline 3.5 & 5 & 0 & 4 & 0 & 2 & 3 \\
\hline 4 (liberalized) & 5 & 9 & 9 & 3 & - & 2 \\
\hline \multirow[t]{2}{*}{ Total } & 63 & 63 & 63 & 18 & 33 & 12 \\
\hline & \multicolumn{6}{|c|}{ Number of Developing (non-OECD) Countries } \\
\hline $\begin{array}{l}\text { Indicator } \\
\text { Value }\end{array}$ & In 1973 & In 1982 & In 1988 & $\begin{array}{c}\text { With no } \\
\text { change in } \\
\text { value } \\
1973-1988\end{array}$ & $\begin{array}{c}\text { With } \\
\text { increase in } \\
\text { value } \\
1973-1988\end{array}$ & $\begin{array}{c}\text { With } \\
\text { decrease in } \\
\text { value } \\
1973-1988\end{array}$ \\
\hline 0 (restricted) & 2 & 1 & 0 & 0 & 2 & - \\
\hline 0.5 & 4 & 5 & 3 & 1 & 6 & 0 \\
\hline 1 & 10 & 8 & 7 & 4 & 5 & 1 \\
\hline 1.5 & 9 & 14 & 13 & 6 & 2 & 1 \\
\hline 2 & 1 & 8 & 9 & 0 & 0 & 1 \\
\hline 2.5 & 5 & 1 & 3 & 2 & 2 & 1 \\
\hline 3 & 4 & 0 & 2 & 0 & 1 & 3 \\
\hline 3.5 & 3 & 0 & 2 & 0 & 0 & 3 \\
\hline 4 (liberalized) & 4 & 5 & 3 & 2 & - & 2 \\
\hline Total & 42 & 42 & 42 & 15 & 15 & 12 \\
\hline
\end{tabular}

Source: Quinn (1997) and authors' calculations. 


\begin{tabular}{|c|c|c|c|c|c|c|c|c|c|}
\hline \multicolumn{5}{|c|}{ Panel 1: Full Sample: Year 1973} & \multicolumn{5}{|c|}{ Panel 4: Developing Countries Year 1973} \\
\hline & & \multicolumn{2}{|c|}{ IMF Indicator } & \multirow{2}{*}{ Total } & & & \multicolumn{2}{|c|}{ IMF Indicator } & \multirow{2}{*}{ Total } \\
\hline & & 0 & 1 & & & & 0 & 1 & \\
\hline Quinn & $0-2$ & 36 & 0 & 36 & Quinn & $0-2$ & 26 & 0 & 26 \\
\hline Indicator & $3-4$ & 10 & 15 & 25 & Indicator & $3-4$ & 4 & 12 & 16 \\
\hline \multicolumn{2}{|l|}{ Total } & 46 & 15 & 61 & \multicolumn{2}{|l|}{ Total } & 30 & 12 & 42 \\
\hline \multicolumn{5}{|c|}{ Panel 2: Full Sample: Year 1982} & \multicolumn{5}{|c|}{ Panel 5: Developing Countries Year 1982} \\
\hline & & \multicolumn{2}{|c|}{ IMF Indicator } & \multirow{2}{*}{ Total } & & & \multicolumn{2}{|c|}{ IMF Indicator } & \multirow{2}{*}{ Total } \\
\hline & & 0 & 1 & & & & 0 & 1 & \\
\hline Quinn & $0-2$ & 38 & 4 & 42 & Quinn & $0-2$ & 32 & 4 & 36 \\
\hline Indicator & $3-4$ & 7 & 12 & 19 & Indicator & $3-4$ & 0 & 6 & 6 \\
\hline \multicolumn{2}{|l|}{ Total } & 45 & 16 & 61 & \multicolumn{2}{|l|}{ Total } & 32 & 10 & 42 \\
\hline \multicolumn{5}{|c|}{ Panel 3: Full Sample: Year 1988} & \multicolumn{5}{|c|}{ Panel 6: Developing Countries Year 1988} \\
\hline & & \multicolumn{2}{|c|}{ IMF Indicator } & \multirow{2}{*}{ Total } & & & \multicolumn{2}{|c|}{ IMF Indicator } & \multirow{2}{*}{ Total } \\
\hline & & 0 & 1 & & & & 0 & 1 & \\
\hline Quinn & $0-2$ & 32 & 0 & 32 & Quinn & $0-2$ & 32 & 0 & 32 \\
\hline Indicator & $3-4$ & 12 & 17 & 29 & Indicator & $3-4$ & 2 & 8 & 10 \\
\hline \multicolumn{2}{|l|}{ Total } & 44 & 17 & 61 & \multicolumn{2}{|l|}{ Total } & 34 & 8 & 42 \\
\hline
\end{tabular}

Source: Authors' calculations. 
Table 5: Dates of Equity Market Liberalization of Emerging Market or Frontier Market Countries

\begin{tabular}{|c|c|c|c|}
\hline Country & $\begin{array}{c}\text { Liberalization } \\
\text { Date }\end{array}$ & Country & $\begin{array}{c}\text { Liberalization } \\
\text { Date }\end{array}$ \\
\hline Argentina & 1989 & Malaysia & 1988 \\
\hline Bangladesh & NL & Mexico & 1989 \\
\hline Brazil & 1991 & Nigeria & 1997 \\
\hline Chile & 1992 & Pakistan & 1991 \\
\hline Colombia & 1991 & Philippines & 1991 \\
\hline Cote d'Ivoire & NL & Portugal & 1986 \\
\hline Egypt & 1997 & Sri Lanka & 1992 \\
\hline Greece & 1987 & South Africa & 1987 \\
\hline India & 1992 & Thailand & NL \\
\hline Indonesia & 1989 & Trinidad \& Tobago & 1989 \\
\hline Israel & 1996 & Tunisia & 1990 \\
\hline Jamaica & NL & Turkey & 1993 \\
\hline Jordan & 1995 & Venezuela & \\
\hline Kenya & NL & Zimbabwe & \\
\hline Korea & 1992 & NL refers to Not Liberalized. & \\
\hline Countries classified as emerging or frontier by the International Finance corporation.
\end{tabular}

Source: Bekaert, Harvey and Lundblad, 2001 
Table 6. Overview of Studies of the Impact of Capital Account Liberalization on Growth

\begin{tabular}{|c|c|c|c|c|}
\hline Study & Countries & Lib. Measure & Dependent Variable and Estimation Method & Main Results for GDP Growth \\
\hline Quinn 1997 & 58 & $\begin{array}{l}\Delta \text { Quinn, between } \\
1988 \text { and } 1958\end{array}$ & Growth in income per capita $1960-1989$. Cross Section, OLS. & $\begin{array}{l}\Delta \text { Quinn significantly raises growth in income per } \\
\text { capita, though no regression is presented with both } \\
\Delta \text { Capital Controls and } \Delta \text { Openness. }\end{array}$ \\
\hline $\begin{array}{l}\text { Klein \& Olivei } \\
\quad 2000\end{array}$ & 67 & Share & $\begin{array}{l}\text { Growth in income per capita, } 1976-1995 \text {. Cross Section, IV. } \\
\text { Change in Financial Depth }(\Delta \mathrm{FD}) \text { as a function of Share and } \\
\text { then per capita income growth as a function of instrumented } \\
\text { value of } \Delta \mathrm{FD} \text { (and initial FD). }\end{array}$ & $\begin{array}{l}\text { Significant effect of Share on } \Delta \mathrm{FD} \text {, though results } \\
\text { seem to be driven by OECD countries in sample. } \\
\text { Significant effect of instrumented values of } \Delta \mathrm{FD} \\
\text { and FD on growth. }\end{array}$ \\
\hline Edwards 2001 & 55 to 62 & $\begin{array}{l}\text { Quinn in 1988; or } \\
\Delta \text { Quinn } 1988- \\
1973\end{array}$ & $\begin{array}{l}\text { Growth in income per capita, } 1980-1989 \text {. Cross Section. WLS } \\
(1985 \text { GDP as weight), IV. Also uses interaction of Quinn in } \\
1988 \text { and } \log (\text { GDP in 1980). }\end{array}$ & $\begin{array}{l}\text { Quinn level significantly raises GDP growth. } \\
\text { Interaction suggests that, at low GDP, opening } \\
\text { capital account may lower GDP growth. }\end{array}$ \\
\hline $\begin{array}{c}\text { Arteta, } \\
\text { Eichengreen. \& } \\
\text { Wyplosz, } 2001\end{array}$ & $\begin{array}{l}51 \\
\text { to } 59\end{array}$ & $\begin{array}{l}\text { Quinn in Initial } \\
\text { Year; or } \\
\Delta \text { Quinn over } \\
\text { relevant period }\end{array}$ & $\begin{array}{l}\text { Growth in income per capita } 1973-81,1982-87,1988-92 \text {, or } \\
\text { pooled for these } 3 \text { periods. Follows Edwards }(2001) \text { but with } \\
\text { OLS rather than WLS and with different instruments. }\end{array}$ & $\begin{array}{l}\text { Quinn significant for pooled results but not for } \\
\text { shorter subsamples. } \Delta \text { Quinn not significant. } \\
\text { Significant effect of interaction of Quinn with either } \\
\text { quality of law or openness. }\end{array}$ \\
\hline $\begin{array}{l}\text { Bekaert, Harvey \& } \\
\text { Lundblad } 2001\end{array}$ & $\begin{array}{c}30 \\
\text { Emerging } \\
\text { markets }\end{array}$ & $\begin{array}{l}\text { Official Dates of } \\
\text { Stock Market } \\
\text { Liberalization }\end{array}$ & $\begin{array}{l}\text { Growth rates in income per capita for various time periods } \\
\text { between } 1981 \text { and 1997, resulting in overlapping data. }\end{array}$ & $\begin{array}{l}\text { Stock market liberalization significantly contributtes } \\
\text { to growth in income per capita, with largest effeets } \\
\text { shortly after liberalization }\end{array}$ \\
\hline O’Donnell 2001 & 94 & $\begin{array}{l}\text { Share or } \\
\text { Volume }\end{array}$ & $\begin{array}{l}\text { Growth in income per capita over } 1971-1994 \text {. Regressions } \\
\text { include interaction between FD and Share, and Volume and FD. }\end{array}$ & $\begin{array}{l}\text { Neither Share nor interaction of Share and FD } \\
\text { significant, but Volume sometimes significant. }\end{array}$ \\
\hline Chanda 2001 & $\begin{array}{c}57 \\
\text { non-OECD }\end{array}$ & Share & $\begin{array}{l}\text { Growth in income per capita over } 1975-1995 . \text { Share interacted } \\
\text { with measure of ethnic heterogeneity. }\end{array}$ & $\begin{array}{l}\text { Share significantly raises growth in ethnically } \\
\text { heterogeneous countries and significantly lowers it } \\
\text { in ethnically homogeneous countries. }\end{array}$ \\
\hline $\begin{array}{l}\text { Grilli \& Milesi- } \\
\text { Ferretti } 1995\end{array}$ & 61 & Share & $\begin{array}{l}\text { Growth in income per capita for five-year non-overlapping } \\
\text { periods during } 1971 \text { - } 1994 \text { period. IV estimation. }\end{array}$ & $\begin{array}{l}\text { No Evidience of a significant effect of Share on } \\
\text { growth of income per capita. }\end{array}$ \\
\hline Rodrik 1998 & About 100 & Share & $\begin{array}{l}\text { Growth in income per capita over } 1975-1995 \text {. Cross Section, } \\
\text { OLS. }\end{array}$ & $\begin{array}{l}\text { No Evidience of a significant effect of Share on } \\
\text { growth of income per capita. }\end{array}$ \\
\hline Kraay 1998 & $\begin{array}{l}64,94, \text { or } \\
117\end{array}$ & $\begin{array}{l}\text { Share; Quinn; } \\
\text { or Volume }\end{array}$ & $\begin{array}{l}\text { Growth in income per capita over } 1985 \text { - 1997. Cross Section. } \\
\text { OLS \& IV. Samples of } 117 \text { (Share); } 94 \text { (Volume); or } 64 \text { (Quinn). }\end{array}$ & $\begin{array}{l}\text { No effect of Share or Quinn on Growth. Coefficient } \\
\text { on Volume significant and positive. }\end{array}$ \\
\hline
\end{tabular}




\section{Table 7}

\section{Growth and Capital Account Liberalization}

\begin{tabular}{|c|c|c|c|c|c|c|c|c|}
\hline \multirow{2}{*}{$\begin{array}{c}\text { Dep. Var. } \\
\Delta \ln Y_{76-95}\end{array}$} & \multicolumn{5}{|c|}{ V. OLS } & \multicolumn{3}{|c|}{ VI. IV } \\
\hline & 1 & 2 & 3 & 4 & 5 & 6 & 7 & 8 \\
\hline $\ln Y_{1976}$ & -0.24 & -0.31 & -0.48 & -0.41 & -0.33 & -0.35 & -0.49 & -0.42 \\
\hline (s.e.) & $(0.04)$ & $(0.05)$ & $(0.08)$ & $(0.09)$ & $(0.05)$ & $(0.06)$ & $(0.08)$ & $(0.06)$ \\
\hline $\ln$ (Educ.) & 0.12 & 0.12 & 0.16 & 0.22 & 0.15 & 0.13 & 0.15 & 0.14 \\
\hline (s.e.) & $(0.05)$ & $(0.05)$ & $(0.08)$ & $(0.10)$ & $(0.05)$ & $(0.05)$ & $(0.09)$ & $(0.05)$ \\
\hline Invest. $74-78$ & 0.007 & 0.01 & 0.02 & 0.02 & 0.007 & 0.01 & 0.02 & 0.008 \\
\hline (s.e.) & $(0.006)$ & $(0.005)$ & $(0.007)$ & $(0.01)$ & $(0.005)$ & $(0.006)$ & $(0.007)$ & $(0.004)$ \\
\hline$\Delta$ Pop. $76-95$ & -0.80 & -0.90 & -1.09 & -1.11 & -0.55 & -0.97 & -1.06 & -0.02 \\
\hline (s.e.) & $(0.17)$ & $(0.17)$ & $(0.31)$ & $(0.35)$ & $(0.27)$ & $(0.18)$ & $(0.33)$ & $(0.33)$ \\
\hline Africa & -0.37 & -0.33 & -0.41 & -0.45 & -0.33 & -0.32 & -0.41 & -0.35 \\
\hline (s.e.) & $(0.11)$ & $(0.10)$ & $(0.17)$ & $(0.17)$ & $(0.11)$ & $(0.11)$ & $(0.17)$ & $(0.13)$ \\
\hline Share $_{76-95}$ & & 0.34 & & & & 0.56 & & \\
\hline (s.e.) & & $(0.12)$ & & & & $(0.17)$ & & \\
\hline Quinn $_{82}$ & & & 0.19 & & & & 0.22 & \\
\hline (s.e.) & & & $(0.06)$ & & & & $(0.06)$ & \\
\hline$\Delta$ Quinn $_{73-88}$ & & & & 0.05 & & & & \\
\hline (s.e.) & & & & $(0.08)$ & & & & \\
\hline $\mathrm{BHL}_{80-95}$ & & & & & 0.43 & & & 1.07 \\
\hline (s.e.) & & & & & $(0.15)$ & & & $(0.28)$ \\
\hline DM p-value & & & & & & 0.13 & 0.52 & 0.01 \\
\hline $\mathrm{R}^{2}$ & 0.47 & 0.52 & 0.59 & 0.44 & 0.53 & 0.50 & 0.58 & 0.34 \\
\hline no. of obs. & 89 & 89 & 52 & 51 & 82 & 87 & 52 & 81 \\
\hline
\end{tabular}

Regressions include a constant (not reported). Robust standard errors.

Definition of Variables:

$\Delta \ln Y_{76-95}=$ growth in $\ln$ real per capita income, 1976 to $1995 ; \ln Y_{1976}=\ln$ real per capita income in 1976; $\ln ($ Educ. $)=\ln \left(\right.$ secondary school enrollment rate); Invest. ${ }_{74-78}=$ Average Investment, 1974 to $1978 ; \Delta$ Pop $_{\cdot 76-95}=$ Population growth, 1976 to 1995; Africa = Dummy variable for African countries; Share ${ }_{76-95}=$ Proportion of years with open capital accounts, 1976 to 1995, from IMF's AREAER; Quinn $82=0$ to 4 measure of capital account openness in 1982 and $\triangle$ Quinn $_{73-88}=$ Difference in 0 to 4 measure of capital account openness between 1973 and 1988, both from Quinn (1997); BHL $_{80-95}=$ Proportion of years between 1980 and 1995 with liberalized stock market, using dates of stock market liberalization from Bekaert, Harvey and Lundblad (2001).

Instruments for Capital Account Liberalization Measures:

Government consumption as proportion of GDP in 1976; Imports as proportion of GDP in 1976; Dummy variables for Latin American countries and East Asian countries; Quinn's 0 to 4 measure of capital account openness in 1973 (for Quinn 82 ) or IMF's AREAER 0/1 value in 1973 (for Share $_{76-95}$ and for $\mathrm{BHL}_{80-95}$ ).

Bold denotes p-value of coefficient 0.05 or less. Italic denotes p-value of coefficient 0.05 to 0.10 . 
Table 8

Differential Effects by OECD Membership or Region

\begin{tabular}{|c|c|c|c|c|c|c|}
\hline $\begin{array}{l}\text { Dep. Var. } \\
\Delta \ln Y_{76-95}\end{array}$ & $\begin{array}{c}1 \\
\text { Share }_{76-95}\end{array}$ & $\begin{array}{c}2 \\
\text { Quinn }_{82}\end{array}$ & $\begin{array}{c}3 \\
\text { BHL } \\
80-95\end{array}$ & $\begin{array}{c}4 \\
\text { Share }_{76-95}\end{array}$ & $\begin{array}{c}5 \\
\text { Quinn }\end{array}$ & $\begin{array}{c}6 \\
\text { BHL }_{80-95}\end{array}$ \\
\hline $\ln \mathrm{Y}_{1976}$ & -0.29 & -0.44 & -0.35 & -0.29 & -0.37 & -0.24 \\
\hline (s.e.) & $(0.05)$ & $(0.07)$ & $(0.06)$ & $(0.07)$ & $(0.09)$ & $(0.06)$ \\
\hline $\ln$ (Educ.) & 0.13 & 0.19 & 0.14 & 0.12 & 0.16 & 0.14 \\
\hline (s.e.) & $(0.05)$ & $(0.08)$ & $(0.05)$ & $(0.05)$ & $(0.09)$ & $(0.05)$ \\
\hline Invest. $74-78$ & 0.01 & $\mathbf{0 . 0 2}$ & 0.004 & 0.01 & 0.009 & 0.002 \\
\hline (s.e.) & $(0.005)$ & $(0.007)$ & $(0.004)$ & $(0.006)$ & $(0.006)$ & $(0.004)$ \\
\hline$\Delta$ Pop.76-95 & -1.00 & -1.33 & -0.17 & -1.03 & -1.16 & -0.69 \\
\hline (s.e.) & $(0.20)$ & $(0.42)$ & $(0.33)$ & $(0.31)$ & $(0.37)$ & $(0.26)$ \\
\hline Africa & -0.30 & -0.35 & -0.22 & -0.33 & -0.43 & -0.22 \\
\hline (s.e.) & $(0.11)$ & $(0.14)$ & $(0.14)$ & $(0.11)$ & $(0.10)$ & $(0.11)$ \\
\hline \multicolumn{7}{|c|}{ Openness Measures by Region } \\
\hline OECD & 0.20 & 0.13 & 0.92 & 0.14 & 0.08 & 0.22 \\
\hline (s.e.) & $(0.11)$ & $(0.05)$ & $(0.28)$ & $(0.11)$ & $(0.05)$ & $(0.13)$ \\
\hline non $-\mathrm{OECD}$ & 0.43 & 0.21 & 1.67 & & & \\
\hline (s.e.) & $(0.16)$ & $(0.07)$ & $(0.49)$ & & & \\
\hline East Asia & & & & 0.69 & 0.26 & 1.15 \\
\hline (s.e.) & & & & $(0.12)$ & $(0.04)$ & $(0.17)$ \\
\hline Latin America & & & & -0.25 & 0.05 & 0.20 \\
\hline (s.e.) & & & & $(0.11)$ & $(0.08)$ & $(0.27)$ \\
\hline Other non-OECD & & & & 0.52 & 0.14 & 0.82 \\
\hline (s.e.) & & & & $(0.38)$ & $(0.12)$ & $(0.33)$ \\
\hline $\begin{array}{l}\text { DM p-value } \\
\text { (OLS or IV) }\end{array}$ & $\begin{array}{c}0.38 \\
\text { (OLS) } \\
\end{array}$ & $\begin{array}{c}0.82 \\
\text { (OLS) }\end{array}$ & $\begin{array}{l}0.02 \\
\text { (IV) }\end{array}$ & $\begin{array}{c}0.23 \\
\text { (OLS) } \\
\end{array}$ & $\begin{array}{c}0.89 \\
\text { (OLS) }\end{array}$ & $\begin{array}{c}0.10 \\
\text { (OLS) }\end{array}$ \\
\hline $\mathrm{R}^{2}$ & 0.53 & 0.61 & 0.37 & 0.61 & 0.72 & 0.62 \\
\hline no. of obs. & 89 & 52 & 81 & 89 & 52 & 82 \\
\hline
\end{tabular}

All estimates using OLS or IV with robust standard errors. Row labeled "p-value of sum" is p-value of sum of capital account liberalization and capital account liberalization times OECD dummy variable coefficients. Regressions include a constant (not reported). All variables as listed in notes to Table 7. Gov. Rep. $=$ Knack and Keefer (1995) measure of degree to which governments do not repudiate contracts, range is $1-10$ and larger values indicate government less likely to repudiate contract.

Bold denotes p-value of coefficient 0.05 or less.

Italic denotes p-value of coefficient 0.05 to 0.10 . 


\section{Table 9}

Including Government Reputation as a Regressor

\begin{tabular}{|c|c|c|c|c|c|c|}
\hline $\begin{array}{l}\text { Dep. Var. } \\
\Delta \ln Y_{76-95}\end{array}$ & $\begin{array}{c}1 \\
\text { Share }_{76-95}\end{array}$ & $\begin{array}{c}2 \\
\text { Quinn }_{82}\end{array}$ & $\begin{array}{c}3 \\
\text { BHL }_{80-95}\end{array}$ & $\begin{array}{c}4 \\
\text { Share }_{76-95}\end{array}$ & $\begin{array}{c}5 \\
\text { Quinn }_{82}\end{array}$ & $\begin{array}{c}6 \\
\text { BHL } 80-95 \\
\end{array}$ \\
\hline $\ln \mathrm{Y}_{1976}$ & -0.41 & -0.42 & -0.40 & -0.36 & -0.33 & -0.37 \\
\hline (s.e.) & $(0.06)$ & $(0.06)$ & $(0.05)$ & $(0.06)$ & $(0.05)$ & $(0.05)$ \\
\hline $\ln$ (Educ.) & 0.16 & 0.12 & 0.13 & 0.15 & 0.10 & 0.13 \\
\hline (s.e.) & $(0.04)$ & $(0.05)$ & $(0.04)$ & $(0.04)$ & $(0.06)$ & $(0.04)$ \\
\hline Invest. $74-78$ & 0.004 & 0.01 & -0.0002 & -0.001 & 0.001 & -0.002 \\
\hline (s.e.) & $(0.004)$ & $(0.004)$ & $(0.003)$ & $(0.004)$ & $(0.003)$ & $(0.003)$ \\
\hline$\Delta$ Pop $_{76-95}$ & -0.09 & -0.46 & -0.02 & -0.10 & -0.43 & -0.01 \\
\hline (s.e.) & $(0.25)$ & $(0.07)$ & $(0.21)$ & $(0.24)$ & $(0.15)$ & $(0.21)$ \\
\hline Africa & -0.46 & -0.46 & -0.48 & -0.50 & -0.53 & -0.49 \\
\hline (s.e.) & $(0.08)$ & $(0.33)$ & $(0.05)$ & $(0.07)$ & $(0.06)$ & $(0.05)$ \\
\hline Gov't. Reputation & 0.17 & 0.18 & 0.17 & 0.14 & 0.14 & 0.15 \\
\hline (s.e.) & $(0.03)$ & $(0.04)$ & $(0.03)$ & $(0.04)$ & $(0.03)$ & $(0.03)$ \\
\hline \multicolumn{7}{|c|}{ Openness Measures by Region } \\
\hline OECD & -0.09 & -0.06 & 0.05 & -0.09 & -0.07 & 0.05 \\
\hline (s.e.) & $(0.09)$ & $(0.05)$ & $(0.09)$ & $(0.08)$ & $(0.04)$ & $(0.09)$ \\
\hline non $-\mathrm{OECD}$ & 0.22 & 0.06 & 0.54 & & & \\
\hline (s.e.) & $(0.12)$ & $(0.06)$ & $(0.12)$ & & & \\
\hline East Asia & & & & 0.43 & 0.13 & 0.72 \\
\hline (s.e.) & & & & $(0.11)$ & $(0.02)$ & $(0.11)$ \\
\hline Latin America & & & & -0.23 & -0.05 & 0.18 \\
\hline (s.e.) & & & & $(0.09)$ & $(0.04)$ & $(0.28)$ \\
\hline Other non-OECD & & & & 0.76 & 0.03 & 0.28 \\
\hline (s.e.) & & & & $(0.39)$ & $(0.06)$ & $(0.30)$ \\
\hline DM p-value & 0.23 & 0.59 & 0.15 & 0.41 & 0.53 & 0.27 \\
\hline $\mathrm{R}^{2}$ & 0.74 & 0.78 & 0.82 & 0.79 & 0.86 & 0.84 \\
\hline no. of obs. & 71 & 50 & 68 & 71 & 50 & 68 \\
\hline
\end{tabular}

All estimates using OLS with robust standard errors. Row labeled "p-value of sum" is pvalue of sum of capital account liberalization and capital account liberalization times OECD dummy variable coefficients. Regressions include a constant (not reported). All variables as listed in notes to Table 7. Gov. Rep. $=$ Knack and Keefer (1995) measure of degree to which governments do not repudiate contracts, range is $1-10$ and larger values indicate government less likely to repudiate contract.

Bold denotes p-value of coefficient 0.05 or less. Italic denotes p-value of coefficient 0.05 to 0.10 . 
Figure 1. Summary of Measures of Capital Account Openness 1

The two measures of liberalization show similar overall patterns, but the openness measure points to greater progress in the 1990s.

- Restriction measure (left scale, inverted)

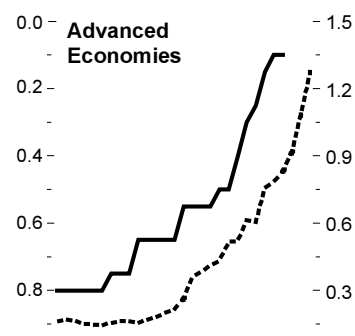

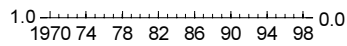

----- Openness measure (right scale)

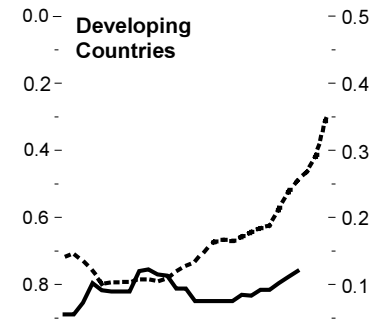

$1.0 \frac{1 \ldots 1 \ldots+1,1 \ldots 1 \ldots}{197074 \quad 78 \quad 82 \quad 86 \quad 90 \quad 94 \quad 98} 0.0$

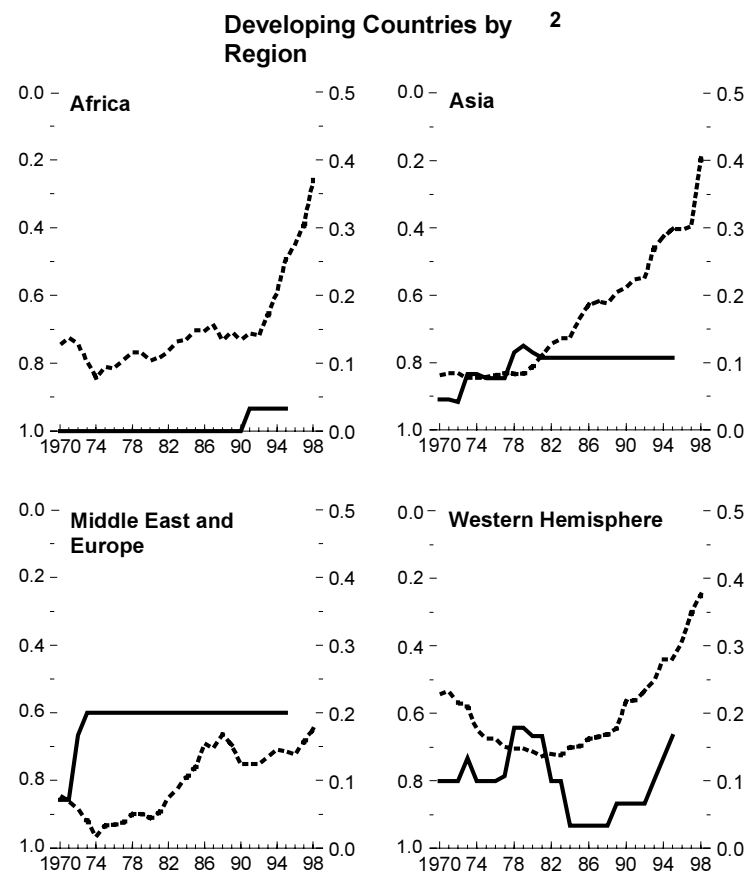

Sources: IMF, Annual Report on Exchange Arrangements and Exchange Restrictions, various issues; International Financial Statistics; and IMF staff callculations.

The restriction measure is calculated as the "average" value of the on/off measure for the country group. The openness measure is calculated as the average stock of accumulated capital flows (as percent of GDP) in a country group.

For country coverage, see Table 4.2 . 